\title{
Attacks on statues associated with social injustice and militarism: New Zealand as a case study
}

\author{
Nick Wilson ${ }^{1 *}$, Amanda C Jones ${ }^{1}$, Andrea Teng ${ }^{1}$, George Thomson ${ }^{1}$ \\ ${ }^{1}$ Department of Public Health, University of Otago Wellington, Wellington, New Zealand \\ * Corresponding author: Prof Nick Wilson, Department of Public Health, University of Otago, \\ Wellington, Mein St, Newtown, Wellington 6021, New Zealand. Phone +61 0212045 523; \\ Email: nick.wilson@otago.ac.nz
}

\begin{abstract}
Objectives

We aimed to explore the potential relationship between social injustice and militarism and attacks on statues in one case study country: New Zealand.

Methods

We performed Internet searches for the existence of the statues and historical attacks in New Zealand (NZ), combined with field visits to all identified statues to examine for injuries and repairs.

Results

Of the 123 statues identified, nearly a quarter $(n=28,23 \%)$ had been attacked at least once (total of 45 separate attack events), with the number of attacks increasing from the 1990s. Attacks involved paint/graffiti (14\% of all statues at least once), nose removal/damage (7\%), decapitation $(5 \%)$, and total destruction (3\%). The risk of attack was relatively higher for statues of royalty $(50 \%)$, military personnel (33\%), explorers (29\%), and politicians $(25 \%)$, compared to other reasons for fame (eg, $0 \%$ for sports players). Statue subjects involved in colonialism and harm to Māori, had 6.61 (95\%CI: 2.30 to 19.9) greater odds (adjusted odds ratio, aOR) of being attacked than other subjects. Similar results were found for statue subjects having any involvement with the military $(\mathrm{aOR}=4.17 ; 95 \% \mathrm{CI}$ : 1.65 to 11.3$)$. Most of the statue subjects were of men $(87 \%)$ and Europeans (93\%). Other ethnicities were 6\% Māori (NZ's Indigenous population comprising $15 \%$ of the population) and $1 \%$ each for Asian and Pacific peoples, who comprise $12 \%$ and $7 \%$ of the population respectively.
\end{abstract}

\section{Conclusions}

There is evidence that attacks on these statues may reflect the role of statue subjects in past social injustices and militarism. Furthermore, the demography of the statue subjects in this country represent historical and current social power relationships - with under-representation of women and non-European ethnic groups. 


\section{Background}

Around the world statues are being attacked, critiqued or removed from prominent public settings. In particular, statues commemorating Confederate leaders and soldiers of the American Civil War are now regularly attacked or removed [1]. Statues of Indigenous peoples that are portrayed in a racist way are also being retired [2], along with those considered sexist (eg, the "Civic Virtue" statue in New York City), and a statue of a famous doctor who committed experiments on slaves (J Marion Sims) [3]. Historical political grievances have resulted in a Ukrainian Parliament law requiring the removal of statues to Lenin, Marx and Engels [4]. This has resulted in the removal of an estimated 5500 statues of Lenin, though two remain in the Chernobyl Exclusion Zone. Attacks on statues can occur over a long period, with one of William III (of Orange) being damaged or destroyed a number of times during the period 1710 to 1928 [5].

Disputes over statues have soured both domestic and international relations. For example, statues of "comfort women" that have strained relationships between Japan and South Korea [6], and also between Japan and the USA [7]. A statue of Alexander the Great has contributed to tension between North Macedonia and Greece - albeit with recent signs of resolution [8]. More dramatically, the removal of a Red Army Soldier statue in Estonia appears to have triggered two nights of riots and a major cyberattack on the country [9]. A giant statue in India that cost \$US 430 million has triggered debate over the misuse of resources [10], and has been criticised for being threatening to non-Hindu citizens [11].

Given this background we aimed to explore the potential relationships between social injustice and militarism and statue attacks in one case study country: New Zealand. Another aim was to describe the sex/ethnic distribution of the statue subjects to determine their representativeness relative to the current population demographics. New Zealand is a country with a history of colonial oppression and wars against Māori (the Indigenous people of New Zealand) and persisting injustices borne by Māori [12]. Other population groups in New Zealand who have traditionally been relatively disempowered include: Pacific peoples, Asian peoples and woman in general (eg, the latter with persisting under-representation in Parliament and unequal pay) [13]. New Zealand also has a diverse ethnic composition: Māori (14.9\% of the population), Asian peoples (11.8\%), and Pacific peoples (7.4\%) [14].

Finally statues in New Zealand can involve substantial investments of community resources. For example, repairing limb fractures to the statue of the British explorer Robert Falcon Scott in Christchurch cost around NZ\$ 560,000 (US\$ 381,000), and this statue has since been insured for NZ\$ 900,000 [15]. Nevertheless, some statues are also neglected for long periods, such as the Earl Jellicoe statue in the City of Invercargill that was missing a nose for a decade.

\section{Methods}

For the purposes of this study we included statues, busts and full-body bas reliefs of named people that had been erected in outdoor public settings in New Zealand and which were approximately life-sized or larger. We aimed to focus on modern-era subjects of statues (from 
the time of the explorer Abel Tasman's first visit in NZ in 1642). We excluded statues of subjects who were: unnamed generic figures (eg, mainly soldiers on war memorials); foundational religious figures (eg, Jesus, Madonna and various saints); pre-European ancestors of Māori; fictional characters from literature and mythological figures. We restricted the sample to public settings, as this is where the prominence of the person represented by the statue is most clearly endorsed, in contrast to statues in places such as cemeteries where it may particularly represent a family's respect for the person. Additional details on our search strategy for identifying statues, field data collection, data coding and analysis are reported in the Supporting Information, along with a list of types of excluded statues in Table S1.

\section{Search strategy}

Briefly, we compiled a list of existing statues by reviewing books and websites on New Zealand sculptures, memorials, monuments and statues. To supplement this list, we also performed searches in Google Images, Google Scholar and a national repository of all New Zealand newspaper issues ("Papers Past") by combining variations of statue terminology (eg, statue, bust), geographic locations (eg, Zealand, Auckland) or other identifiers (eg, 'Māori', names of famous New Zealanders [16]). Subsequent to the original searches, we incidentally located six additional statues as a result of both further internet searches $(n=3)$, and field work $(n=3)$ up to the last inclusion date (13 April 2019 when the statue of Alex Lithgow was unveiled). This indicted an upper estimate of the sensitivity of our initial strategy at $94 \%$.

Identifying a statue as per the above search strategies frequently revealed historical information about intentional and unintentional injuries to the statue. We performed additional searches in Google Images, Google Scholar and Papers Past with attack-related search terms (eg, statue and vandalism, statue decapitation). For all statues with any history of damage, we made further searches for information about the possible motives for such damage.

\section{Field data}

Site visits to all the statues that were still outdoors were conducted between September 2018 and August 2019. For each statue, photographs were taken of the setting, all sides of the statue, and any associated plaques or information boards. In particular, the statues were closely examined for evidence of past and current injuries (including attacks with paint).

\section{Data coding and analysis}

Data from internet searches and field visits were collated in an Excel file and analysed. The denominator used was for all statues unveiled at any time up to the last inclusion date (13 April 2019). This included all statues that were destroyed $(n=3)$, stolen $(n=1)$, or moved from outdoors and into interior settings $(n=14)$. If a stolen statue was replaced $(n=1)$, the replacement statue was counted as a new statue in the denominator. Each statue was coded for the following characteristics: time (eg, unveiling year), setting (eg, city), the statue subject's general characteristics (eg, sex), the subject's primary reason for fame (eg, politician), and the features of the statue (eg, statue material).

We defined a statue attack as being where there was documentation of an attack or from our field observations of obvious repairs, missing body parts (eg, noses), paint remnants, or graffiti. 
Attack documentation consisted of reports in Papers Past (a collection of New Zealand and Pacific text items) or in online media reports.

We developed four a priori potentially controversial characteristics that may have made these statues controversial, at least to some of the public. We reviewed all of the identified statues to determine if the subject of the statue met any of these definitions; the characteristic categories were not mutually exclusive:

- New Zealand colonialism or harm to Māori: The statue subject was involved in colonialism in New Zealand or involved in specific harm to Māori. This was based on the grounds that such injustice may contribute to grievances that could contribute to subsequent statue attacks, based on international patterns of statue attack.

- Military decision-maker: The statue subject was a military decision-maker with any officer rank (for commissioned officers) or a political or other leader (ie, king or queen) playing a role in a war effort. This was based on the grounds that such leaders may be blamed for militarism in general or specific military events where relatives or friends were killed or injured, or particular injustices were done (eg, harming civilians).

- Other military involvement: The statue subject had any relationship to the military (ie, as per the point directly above), but including all military ranks. This was based on the potential for statues may be a focus of pacifist, anti-military and other objections to war, and the focus of activity by those impacted by military actions or thinking.

- Militaristic element shown on the statue: The actual statue had a militaristic feature built into it, such as a military uniform, firearm or sword etc.

The list of those statue subjects that fitted in these categories is detailed in the Supporting Information (Table S3, and Table S2 for the militaristic elements).

Statistical analyses were conducted using EpiInfo and OpenEpi. For the logistic and linear regression relating to risk factors for statue attack, we used $\mathrm{R}$ (version 3.4.3; 2017-11-30).

\section{Results}

\section{Description of the statues}

We identified 123 outdoor statues of modern-era named people in public settings throughout New Zealand (Table 1; additional details in the Supporting Information Table S2). Since the first such statue was unveiled in 1867 , there was a U-shaped pattern of statue unveiling, with an initial peak in the 1920s, no unveilings in the 1940s and 1950s, and then with increased unveilings from the 1990s onwards (Fig. 1). These statues were primarily of men (87\%) and Europeans (93\%). Other ethnicities were 6\% Māori and 1\% each for Asian and Pacific peoples. The most common primary reason for notability in these statue subjects was being a military personnel (17\%), then a politician (16\%), and then an explorer or artist/writer (each $11 \%)$. There were more sports players $(9 \%)$ than doctors $(2 \%)$ or scientists $(2 \%)$. Particular individuals also dominated: $24 \%$ of the statues were of people who had multiple statues ie, Captain Cook led with five; and Queen Victoria and Robbie Burns had four each. 
Most statues were made of bronze (68\%). Militaristic elements were present in 22\% eg, military uniforms, swords, and firearms etc. Three statues had no associated name plaque and use of Māori language (Te Reo) on the plaque or monument was uncommon (6\%).

Fig. 1: Number of statues of named individuals unveiled in public outdoor settings in New Zealand and first intentional attacks on each statue by decade

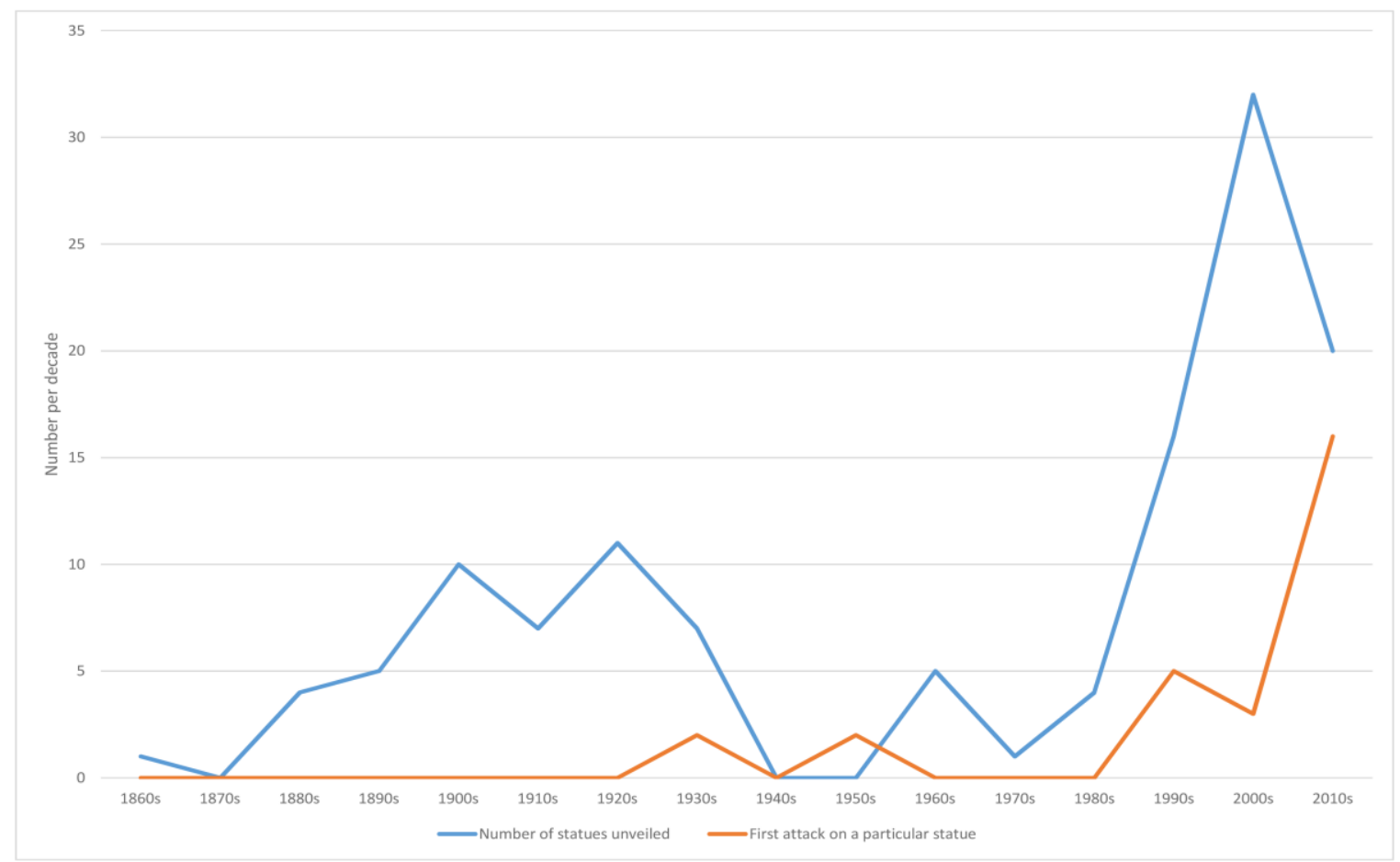

Note: For the last decade, data collection was not quite complete, ie, up to the 13 April 2019 (unveiling of the Lithgow statue)

\section{Statue attacks}

Of the 123 statues, $28(23 \%)$ had been intentionally attacked at least once. Recorded statue attacks first began in the 1930s, but the number of attacks has risen since the 1990s (Fig. 1). There were an estimated 45 separate attacks on 28 statues (mean $=0.37$ attacks per statue out of all 123 statues, or 7.8 attacks per 1000 statue-years of existence, Table 2). The most common type of attack was a paint attack or graffiti (14\% of all statues for any attack), followed by nose removal or damage (7\%) (Fig. 2 and the Supporting Information Fig. S1). Decapitation occurred a total of 11 times among six statues, with two statues decapitated multiple times (eg, five times for the statue of King George V at Matakana, Fig. 2). Three statues were destroyed in attacks and another stolen (Admiral Tait in Timaru). An attempt to topple a new bronze statue (of the military hero Charles Upham) with a concrete cutter by an anti-war demonstrator was stopped by nearby people and this statue was fully repaired [17]. 
Fig. 2: Panel A: Statue of the poet Robbie Burns (Hokitika) showing nose damage and suboptimal hand repair. Panel B: Statue of an explorer Abel Tasman whose expedition killed Māori when arriving in New Zealand. Panel C: Statue of Queen Victoria (Dunedin) with a suboptimal nose repair (all preceding photographs by the $2^{\text {nd }}$ author, 2018/2019). Panel D: Decapitated statue of King George V (Matakana) based on a screen shot of the Google Street View image in 2013.

A

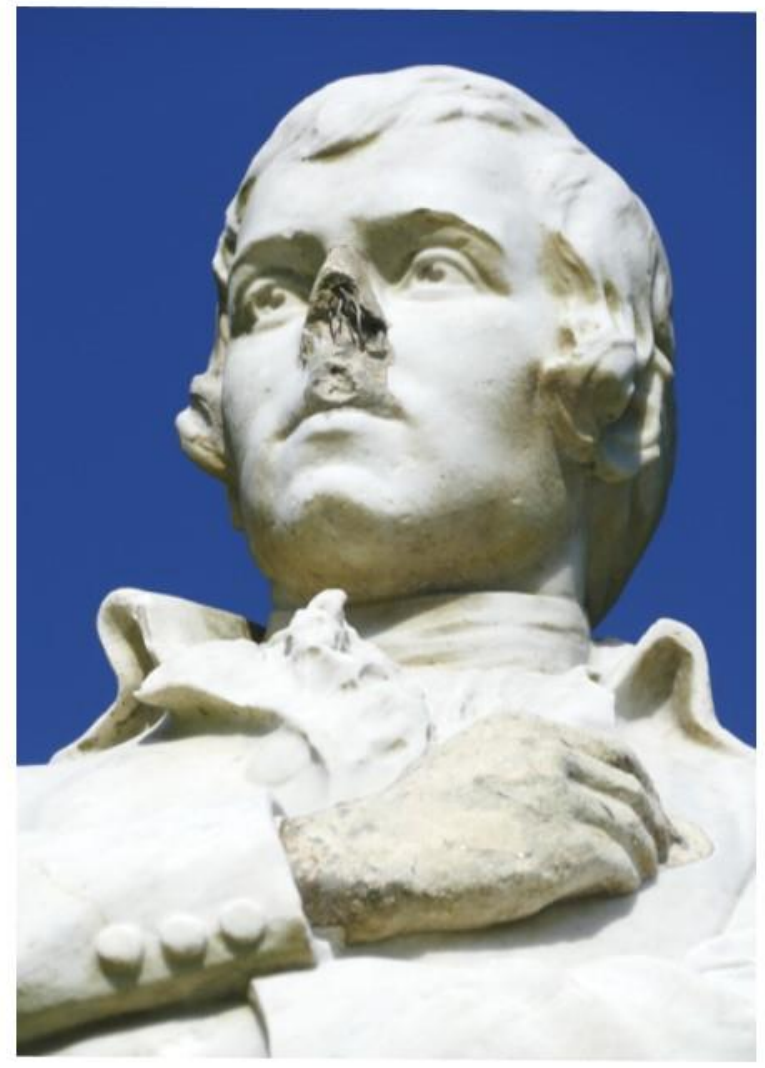

C

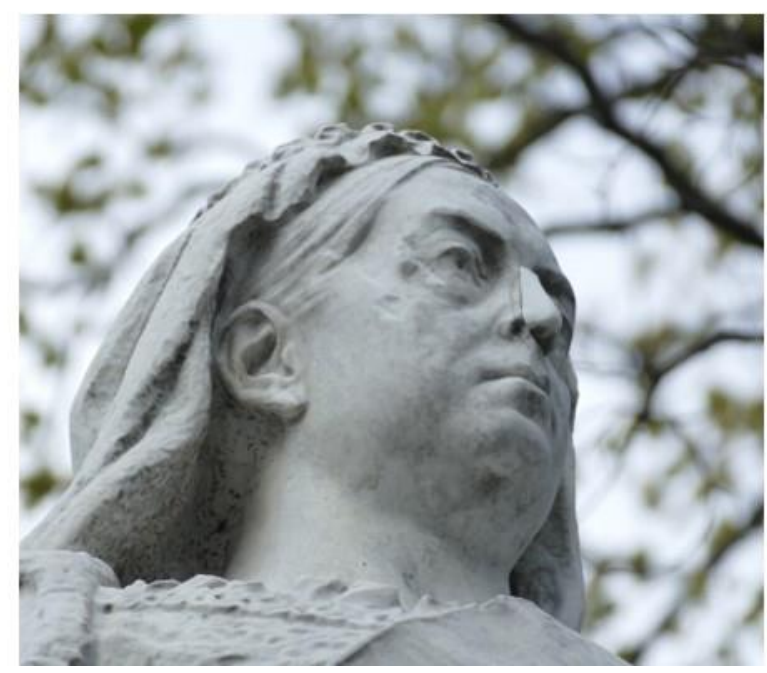

B

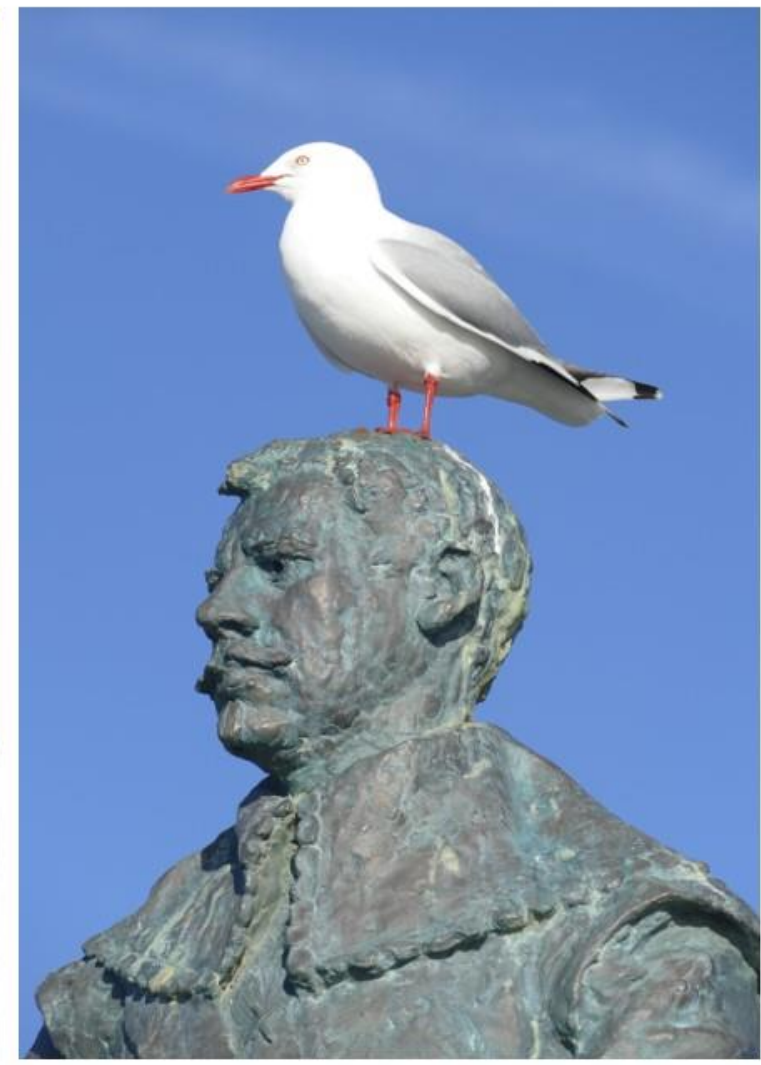

D

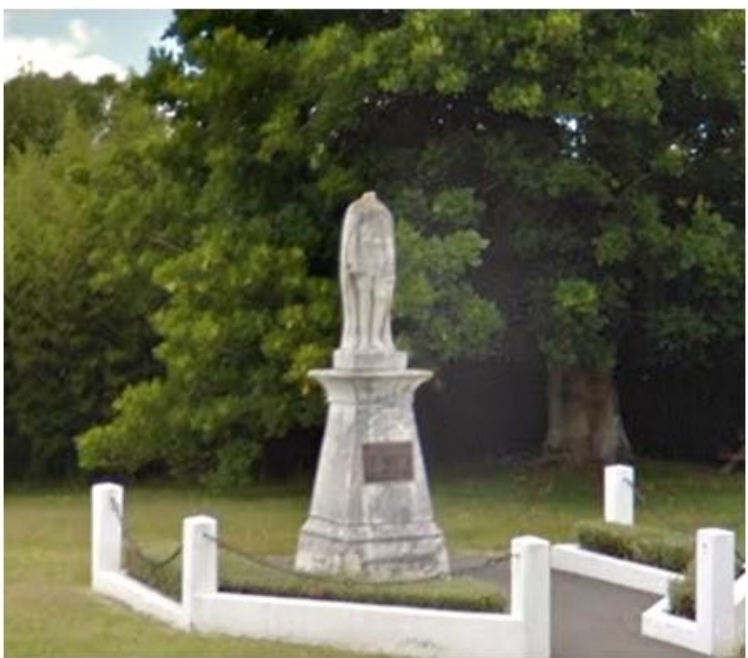




\section{Risk factors for statue attack}

Statue characteristics that were significantly associated with any attack included being an older statue (ie, an earlier unveiling date), and not being made of bronze (eg, being made of marble) (Table 3 ). Risk of attack was relatively high for: royalty (50\%), military personnel (33\%), explorers $(29 \%)$, and politicians $(25 \%)$; but zero for sports players $(0 \%)$.

In the logistic regression analysis adjusting for statue age and material (bronze vs other material), the statues of potentially controversial subjects involved in colonialism and harm to Māori (based on our a priori classification) were more likely to have been attacked: adjusted odds ratio (aOR) of 6.61 (95\%CI: 2.30 to 19.9), compared to all other statues. Similarly for statue subjects having any involvement with the military compared to all other statues (aOR=4.17; 95\%CI: 1.65 to 11.3) (Table 4). The latter relationship with the military was also apparent when just considering statues of high ranked subjects (commissioned officers or political leaders) and if the statue displayed a militaristic element (statistically significant aORs of 2.86 and 2.44 respectively).

All these same four listed potentially controversial characteristics (relating to colonialism/harm to Māori, two types of military involvement and militaristic elements) were also statistically significant in terms of having higher numbers of past attacks when compared to the other statues (Table 5). In particular the statue subjects involved in colonialism or harm to Māori had the most additional attacks on average (ie, 1.0 extra, 95\%CI: 0.7 to 1.4 )

Additional qualitative analysis also indicated that of the attacked statues, nearly half (46\%, 13/28) had some evidence to suggest that attack directly motivated by the statue subject's past colonial or military activity (see the Supporting Information Table S4 for more details on each attacked statue). 
Table 1: Characteristics of all the 123 outdoor statues of named people in public settings throughout New Zealand identified in this survey

\begin{tabular}{|c|c|c|c|}
\hline Characteristic & $\mathbf{N}$ & $\%$ & Comment \\
\hline \multicolumn{4}{|l|}{ Time } \\
\hline $\begin{array}{l}\text { Unveiling year: median } \\
\text { calendar year } \\
\text { (interquartile range [IQR]) }\end{array}$ & $\begin{array}{l}1993 \\
(1923 \text { to } \\
2009)\end{array}$ & - & $\begin{array}{l}\text { See Fig. } 1 \text { for the time trends by decade. Full range } \\
\text { was from } 1867 \text { to } 2019 \text {. }\end{array}$ \\
\hline - Mode & 2009 & - & There were 15 statues unveiled in this year. \\
\hline Statue age: mean (years) & $\begin{array}{l}47.0(\mathrm{SD}= \\
\quad 45.6)\end{array}$ & - & $\begin{array}{l}\text { From unveiling date to the end of the year } 2018 \text { if } \\
\text { still standing (otherwise to date of destruction, theft } \\
\text { or to being moved indoors). }\end{array}$ \\
\hline - median (IQR) & $\begin{array}{l}25.5(7.5 \text { to } \\
96.3)\end{array}$ & - & As above. \\
\hline Statue-years (cumulative) & 5780 & - & As above. \\
\hline \multicolumn{4}{|l|}{ Setting } \\
\hline - City & 91 & $74.0 \%$ & \\
\hline - Town & 31 & $25.2 \%$ & \\
\hline - Rural & 1 & $0.8 \%$ & \\
\hline $\begin{array}{l}\text { Statue moved from } \\
\text { outdoors to an indoor } \\
\text { location }\end{array}$ & 14 & $11.4 \%$ & $\begin{array}{l}\text { Most of these }(n=12) \text { were moved on a temporary } \\
\text { basis to facilitate earthquake repairs on an adjacent } \\
\text { building in Christchurch. }\end{array}$ \\
\hline \multicolumn{4}{|l|}{$\begin{array}{l}\text { Statue subject } \\
\text { characteristics }\end{array}$} \\
\hline \multicolumn{4}{|l|}{ Statues per subject } \\
\hline - One & 93 & $75.6 \%$ & \\
\hline - Two or more & 30 & $24.4 \%$ & The most frequent was for Captain Cook $(n=5)$. \\
\hline \multicolumn{4}{|l|}{ Sex } \\
\hline - Male & 107 & $87.0 \%$ & \\
\hline - Female & 16 & $13.0 \%$ & \\
\hline \multicolumn{4}{|l|}{ Ethnicity } \\
\hline - European & 114 & $92.7 \%$ & Of these, $13 \%(n=15)$ were female. \\
\hline - Māori & 7 & $5.7 \%$ & Of these, $14 \%(n=1)$ were female. \\
\hline - Pacific peoples & 1 & $0.8 \%$ & $\begin{array}{l}\text { This single statue was of Michael Jones, a rugby } \\
\text { player (Supporting Information Fig. S2). }\end{array}$ \\
\hline - Asian peoples & 1 & $0.8 \%$ & $\begin{array}{l}\text { This was of Mahatma Gandhi. There were nil } \\
\text { statues of Asian people who had lived in NZ. }\end{array}$ \\
\hline $\begin{array}{l}\text { On a list of } 100 \text { most } \\
\text { famous New } \\
\text { Zealanders[16] }\end{array}$ & 19 & $15.4 \%$ & $\begin{array}{l}\text { Includes those with multiple statues erected (eg, } \\
\text { George Grey, Edmund Hillary, Peter Snell). }\end{array}$ \\
\hline \multicolumn{4}{|c|}{ Statue subject - primary reason for fame } \\
\hline - Military personnel* & 21 & $17.1 \%$ & Included 4 Victoria Cross winners. \\
\hline - Politician & 20 & $16.3 \%$ & Prime ministers, members of parliament, mayors. \\
\hline - Explorer & 14 & $11.4 \%$ & Eg, Abel Tasman Fig. 2. \\
\hline
\end{tabular}




\begin{tabular}{|c|c|c|c|}
\hline Characteristic & $\mathbf{N}$ & $\%$ & Comment \\
\hline - Artist/writer & 13 & $10.6 \%$ & \\
\hline - Sports player & 11 & $8.9 \%$ & $\begin{array}{l}\text { Eg, Michael Jones, a rugby player (Supporting } \\
\text { Information Fig. S2). }\end{array}$ \\
\hline - Business leader & 10 & $8.1 \%$ & \\
\hline - Founder (eg, of a town) & 8 & $6.5 \%$ & \\
\hline - Social activist & 7 & $5.7 \%$ & \\
\hline - Royalty & 6 & $4.9 \%$ & King George V $(n=2)$ and Queen Victoria $(n=4)$. \\
\hline - Other & 13 & $10.4 \%$ & $\begin{array}{l}\text { Religious leader }(\mathrm{n}=2) \text {, doctor (2), Māori leader (2), } \\
\text { scientist (2), local character ( } \mathrm{n}=2 \text {; "swagger" and } \\
\text { legendary sheep rustler), and none of the above (ie, } \\
\mathrm{n}=3 \text {; architect, aviator, engineer/philanthropist). }\end{array}$ \\
\hline \multicolumn{4}{|l|}{ Statue features } \\
\hline \multicolumn{4}{|l|}{ Statue material } \\
\hline - Bronze & 84 & $68.3 \%$ & \\
\hline - Other materials & 39 & $31.7 \%$ & Included marble, granite, concrete. \\
\hline $\begin{array}{l}\text { No plaque (ie, unnamed } \\
\text { statue) }\end{array}$ & 3 & $2.9 \%$ & $\begin{array}{l}\text { Rudyard Kipling, John Ruskin, Camille Malfroy. The } \\
\text { denominator }(n=105) \text { was the number of field } \\
\text { observations. }\end{array}$ \\
\hline $\begin{array}{l}\text { Statue had a militaristic } \\
\text { element }\end{array}$ & 27 & $22.0 \%$ & $\begin{array}{l}\text { Includes any of: military uniforms, swords, firearms, } \\
\text { and spears. There were statues of people related to } \\
\text { six different wars that involved NZ: the Musket } \\
\text { Wars, the NZ Wars, South African War, First World } \\
\text { War, Second World War and the Vietnam War. }\end{array}$ \\
\hline $\begin{array}{l}\text { Any Māori language text } \\
\text { on the plaque or statue } \\
\text { structure }\end{array}$ & 7 & $5.7 \%$ & $\begin{array}{l}\text { For any text but excluding the Māori name of the } \\
\text { statue subject in one case. }\end{array}$ \\
\hline
\end{tabular}

* This was for the "primary" reason for fame. For our analysis of potential controversial military personnel (in Tables 4 and 5) we used an expanded definition to all those with a role military decision-maker (which included various people whose primary reason for fame was as a politician or King) (detailed in the Supporting Information, Table S3).

Similarly, for any involvement in the military which also included the just mentioned group (some politicians) as well as explorers (eg, who were in the navy etc).

Table 2: Type of injuries from attacks on the outdoor statues in this survey

\begin{tabular}{|l|c|c|l|}
\hline $\begin{array}{l}\text { Type of } \\
\text { intentional injury }\end{array}$ & $\mathbf{N}$ & $\%$ & \multicolumn{1}{c|}{ Additional details } \\
\hline $\begin{array}{l}\text { Any intentional } \\
\text { physical damage or } \\
\text { paint attack }\end{array}$ & 28 & $22.8 \%$ & $\begin{array}{l}\text { Some statues had multiple attacks ie, an estimated 42 separate } \\
\text { attack events on these 28 statues (mean = 0.34 attacks per statue } \\
\text { out of all 123 statues, or 7.3 attacks per 1000 statue-years of } \\
\text { existence). See Fig. 1 for the time trends of first attacks by decade. }\end{array}$ \\
\hline $\begin{array}{l}\text { - Any paint } \\
\text { attack/graffiti }\end{array}$ & 17 & $13.8 \%$ & $\begin{array}{l}\text { Some of these attacks were not historically documented but were } \\
\text { inferred from paint remnants on the statue from field observations. } \\
\text { We included attacks with words painted on the statue and one attack } \\
\text { with nugget (shoe polish). For statues that reported "multiple" paint } \\
\text { attacks, we used 2 attacks per statue in the analysis. There were a } \\
\text { total of 20 known paint attacks used in the analysis. }\end{array}$ \\
\hline
\end{tabular}




\begin{tabular}{|l|c|c|l|}
\hline $\begin{array}{l}\text { Type of } \\
\text { intentional injury }\end{array}$ & $\mathbf{N}$ & $\%$ & \multicolumn{1}{c|}{ Additional details } \\
\hline $\begin{array}{l}\text { - Any nose } \\
\text { removal/damage }\end{array}$ & 8 & $6.5 \%$ & $\begin{array}{l}\text { In most cases the nose was removed (eg, Fig. 2, Supporting } \\
\text { Information Fig. S1). For 3 attacks on bronzes there was just denting } \\
\text { of the nose. For one statue with reported "multiple" nose losses we } \\
\text { used "2 attacks" in the analysis. There were a total of 9 attacks used } \\
\text { in the analysis. }\end{array}$ \\
\hline - Any decapitation & 6 & $4.9 \%$ & $\begin{array}{l}\text { Included statues: John Ballance (Whanganui) [twice]; John Ballance } \\
\text { (Wellington); Robbie Burns (Timaru); King George V (Matakana) [five } \\
\text { times, eg, Fig. 2]; George Grey (Auckland); Field Marshal Kitchener } \\
\text { (Auckland). Two statues had multiple decapitations so there were 11 } \\
\text { decapitations among these six statues. }\end{array}$ \\
\hline $\begin{array}{l}\text { - Complete } \\
\text { destruction or } \\
\text { removal }\end{array}$ & 3 & $2.4 \%$ & $\begin{array}{l}\text { Included statues: John Ballance (Whanganui), following a period of } \\
\text { being headless; the bust of Admiral Tait (Timaru) was stolen; after } \\
\text { decapitation, the remains of the Kitchener statue (Auckland) were } \\
\text { taken down and the statue was never replaced. }\end{array}$ \\
\hline - Any other injuries & 8 & $6.5 \%$ & $\begin{array}{l}\text { These included the removal of a foot and hands, damage to fingers, } \\
\text { denting of parts of the head (other than nose), and damage from an } \\
\text { attempt to topple a statue with a concrete cutter. }\end{array}$ \\
\hline
\end{tabular}

Table 3: Characteristics of attacked $(n=28)$ and non-attacked $(n=95)$ statues (for any attacks over the "lifetime" of each statue)

\begin{tabular}{|c|c|c|c|}
\hline Characteristics & $\begin{array}{l}\text { Risk of attack in } \\
\text { group of interest }\end{array}$ & $\begin{array}{c}\text { Risk of attack in } \\
\text { comparison } \\
\text { group }\end{array}$ & P-value* \\
\hline \multicolumn{4}{|l|}{ Statue subject characteristics } \\
\hline Male ( $n=107)$ (vs comparison group: female) & $24.3 \%$ & $12.5 \%$ & 0.3171 \\
\hline European $(n=114)$ vs other ethnicities & $23.7 \%$ & $11.1 \%$ & 0.4372 \\
\hline \multicolumn{4}{|l|}{ Statue subject - primary reason for fame ${ }^{\star \star}$} \\
\hline Royalty (king or queen) $(n=6)$ vs not royalty & $50.0 \%$ & $21.4 \%$ & 0.1543 \\
\hline Military personnel $^{* * *}(n=21)$ vs other & $33.3 \%$ & $20.6 \%$ & 0.1133 \\
\hline Explorer $(n=14)$ vs other & $28.6 \%$ & $22.0 \%$ & 0.5823 \\
\hline Politician ( $n=20)$ vs other & $25.0 \%$ & $22.3 \%$ & 0.7798 \\
\hline Sports player $(n=11)$ vs other & $0.0 \%$ & $20.0 \%$ & 0.0960 \\
\hline \multicolumn{4}{|l|}{ Statue features } \\
\hline $\begin{array}{l}\text { Statue mean age (years) in attacked statues } \\
\text { (vs not attacked) }\end{array}$ & $\begin{array}{l}62.8 \text { years } \\
(\mathrm{SD}=43.0)\end{array}$ & $\begin{array}{l}42.3 \text { years } \\
(\mathrm{SD}=45.5)\end{array}$ & 0.0365 (ANOVA) \\
\hline $\begin{array}{l}\text { Not made out of bronze }(n=39) \text { (ie, marble, } \\
\text { concrete, composite materials) vs bronze }\end{array}$ & $38.5 \%$ & $15.5 \%$ & 0.0034 \\
\hline
\end{tabular}

${ }^{*}$ Mid-P exact test (unless otherwise stated).

** There were no attacks on statues of: social activists $(n=7)$, religious leaders $(n=3)$, doctors $(n=2)$, or scientists $(\mathrm{n}=2)$.

${ }^{* * *}$ See explanatory footnote following Table 1. 
Table 4: Risk of attack by potentially controversial aspects, including with adjustment for age and statue material (for any attacks over the "lifetime" of each statue)

\begin{tabular}{|c|c|c|c|c|}
\hline $\begin{array}{l}\text { Potentially controversial } \\
\text { aspect }\end{array}$ & $\begin{array}{l}\text { Risk of } \\
\text { attack in } \\
\text { group of } \\
\text { interest }\end{array}$ & $\begin{array}{l}\text { Risk of } \\
\text { attack in } \\
\text { comparis } \\
\text { on group }\end{array}$ & Crude odds ratio (OR) & $\begin{array}{l}\text { Adjusted odds ratio } \\
\text { (aOR) on logistic } \\
\text { regression, (95\%Cl) } \\
\text { and p-value; } \\
\text { (adjustment for statue } \\
\text { age and material) }\end{array}$ \\
\hline $\begin{array}{l}\text { Statue subject involved in } \\
\text { colonialism in NZ or specific } \\
\text { harm to Māori }(n=22)\end{array}$ & $\begin{array}{l}59.1 \% \\
(13 / 22)\end{array}$ & $\begin{array}{c}14.9 \% \\
(15 / 101)\end{array}$ & $\begin{array}{l}8.25(3.06 \text { to } 23.6) \\
p<0.0001\end{array}$ & $\begin{array}{c}6.61(2.30 \text { to } 19.9) ; \\
p=0.0005\end{array}$ \\
\hline $\begin{array}{l}\text { Statue subject was a military } \\
\text { decision-maker } \\
\text { (commissioned officer rank } \\
\text { or political leader) }(n=42)\end{array}$ & $\begin{array}{l}38.1 \% \\
(16 / 42)\end{array}$ & $\begin{array}{l}14.8 \% \\
(12 / 81)\end{array}$ & $\begin{array}{l}3.54(1.49 \text { to } 8.65) ; \\
\quad p=0.0046\end{array}$ & $\begin{array}{c}2.86(1.16 \text { to } 7.19) ; \\
p=0.0229\end{array}$ \\
\hline $\begin{array}{l}\text { Statue subject had any } \\
\text { involvement with the military } \\
(n=51)\end{array}$ & $\begin{array}{l}39.2 \% \\
(20 / 51)\end{array}$ & $\begin{array}{l}11.1 \% \\
(8 / 72)\end{array}$ & $\begin{array}{c}5.16(2.11 \text { to } 13.7) \\
\mathrm{p}=0.0005\end{array}$ & $\begin{array}{l}4.17\left(\begin{array}{l}(1.65 \text { to } 11.3) \\
\mathrm{p}=0.0034\end{array}\right.\end{array}$ \\
\hline $\begin{array}{l}\text { Statue had a militaristic } \\
\text { element (see Table 1) }(n=27)\end{array}$ & $\begin{array}{l}40.7 \% \\
(11 / 27)\end{array}$ & $\begin{array}{l}17.7 \% \\
(17 / 96)\end{array}$ & $\begin{array}{c}3.19(1.25 \text { to } 8.12) \\
p=0.0143\end{array}$ & $\begin{array}{c}2.44(0.86 \text { to } 6.84) \\
p=0.0890\end{array}$ \\
\hline
\end{tabular}

Table 5: Comparison on frequency of attacks by statue characteristics (linear regression analyses)

\begin{tabular}{|c|c|c|c|c|}
\hline Characteristic & $\begin{array}{l}\text { Mean } \\
\text { number of } \\
\text { attacks for } \\
\text { group of } \\
\text { interest }\end{array}$ & $\begin{array}{l}\text { Mean number } \\
\text { of attacks for } \\
\text { the } \\
\text { comparison } \\
\text { group }\end{array}$ & $\begin{array}{c}\text { P-value } \\
\text { (Kruskal- } \\
\text { Wallis [KW] } \\
\text { test for two } \\
\text { groups) on } \\
\text { crude } \\
\text { analysis }\end{array}$ & $\begin{array}{c}\text { Mean } \\
\text { difference on } \\
\text { adjusted } \\
\text { analysis } \\
\text { (statue age and } \\
\text { material) } \\
(95 \% \mathrm{Cl})\end{array}$ \\
\hline \multicolumn{5}{|l|}{ Statue characteristics } \\
\hline $\begin{array}{l}\text { Statue unveiled before World War } 2 \\
(\mathrm{n}=44) \text { vs after this war started }\end{array}$ & 0.66 & 0.20 & 0.0051 & - \\
\hline $\begin{array}{l}\text { Statue made of bronze }(n=84) \text { vs other } \\
\text { material (ie, marble, concrete, } \\
\text { composite materials) }\end{array}$ & 0.23 & 0.67 & 0.0048 & - \\
\hline \multicolumn{5}{|l|}{ Potentially controversial aspect } \\
\hline $\begin{array}{l}\text { Statue subject involved in colonialism } \\
\text { in NZ or specific harm to Māori }(n=22)\end{array}$ & 1.27 & 0.17 & $<0.0001$ & $\begin{array}{c}1.03 \\
(0.68 \text { to } 1.37)\end{array}$ \\
\hline $\begin{array}{l}\text { Statue subject was a military decision- } \\
\text { maker (commissioned officer rank or } \\
\text { political leader) }(n=42)\end{array}$ & 0.69 & 0.20 & 0.0024 & $\begin{array}{c}0.40 \\
(0.10 \text { to } 0.70)\end{array}$ \\
\hline $\begin{array}{l}\text { Statue subject had any involvement } \\
\text { with the military }(n=51)\end{array}$ & 0.69 & 0.14 & 0.0002 & $\begin{array}{c}0.46 \\
(0.17 \text { to } 0.75)\end{array}$ \\
\hline $\begin{array}{l}\text { Statue had a militaristic element (see } \\
\text { Table 1) }(n=27)\end{array}$ & 0.78 & 0.25 & 0.0082 & $\begin{array}{c}0.44 \\
(0.08 \text { to } 0.81)\end{array}$ \\
\hline
\end{tabular}




\section{Discussion}

\section{Main findings and interpretation}

This study found that $23 \%$ of New Zealand's outdoor public statues had been attacked at least once (a total of 45 attacks), with an increase in the number of attacks in the last three decades. Injuries ranged from paint attacks that can be relatively easy to repair, to decapitation and even complete statue destruction. We found that attacks were significantly more common on statues where the statue subject was involved in colonialism or specific harm to Māori, or was linked with militarism. This is consistent with the international pattern of statue attacks (see Introduction). Indeed, attacks have occurred internationally on some of the exact same figures elsewhere eg, Captain Cook in Australia [18], and King George V in South Africa [19].

The quantitative analysis results were also supported by those from the qualitative analysis that indicated that of the attacked statues, nearly half (46\%) had some evidence linking the statue subject to colonial or military activity eg, attacks on the statues of former Prime Minister Ballance [20], and George Grey [21] (Supporting Information Table S4). Furthermore, New Zealand's participation in international conflicts might explain attacks on Field Marshal Kitchener (South African War and the First World War) and former Prime Minister Holyoake (Vietnam War). Nevertheless, some of the other attacks might be more in the domain of "pranks" as per the decapitation of the poet Robbie Burns in Timaru and the repeated nose thefts of the philanthropist Atkinson in Auckland.

The disproportionate domination of statue subjects by European males (relative to Māori, Pacific peoples, Asian peoples and women) seems likely to reflect historical and persisting power relations in New Zealand society. Nevertheless, there is a renaissance of Māori art forms that include art works outside traditional European definitions of statues eg, construction of "pou" (involving ancestor representations) as well as statues in private settings such as marae, and in urupā (Māori cemeteries) [22].

\section{Study strengths and limitations}

A strength of this study was that it is the first full national survey of statues and statue attacks in any nation (to the best of our knowledge), and included field visits to all the identified outdoor statues. This achievement was facilitated by New Zealand having a relatively small population and having detailed historical documentation with the digitalisation of historic New Zealand newspapers (ie, Papers Past). Our field work was also assisted by the low-quality of some statue repair work which allowed for the ready diagnosis of past injuries eg, the crude nose replacements for Queen Victoria and Earl Jellicoe (Fig. 2 and Supporting Information Fig. S1). Similarly for statues being left unrepaired eg, the missing nose on Robbie Burns in the town of Hokitika (Fig. 2).

A possible limitation was that we may still have missed some statues and the historical documentation of their past attacks with our search strategies (eg, as per the upper estimate of the sensitivity of our initial strategy at 94\%). It might be that to avoid additional attacks, the police and various local government agencies purposefully avoided media coverage of an attack and that the repairs were conducted discretely. Also, although we used cameras with telephoto capacity, we might have missed some signs of injuries or repairs of statues on tall plinths (eg, as per one example shown in Fig. S3, Supporting Information). Our definitions were also somewhat 
conservative in that for physical attacks we did not include damage to: secondary figures which were part of an overall memorial (eg, the statue of a Māori warrior beneath a statue of George V in Rotorua was completely destroyed in a 1936 attack); and damage to non-body parts of the main statue (eg, to walking sticks etc). We also conservatively counted reports of "multiple" past attacks (eg, theft of a nose) as only "two" attacks.

\section{Potential policy responses}

No policy-maker is likely to be particularly concerned with attacks of statues in their decisions around social policy interventions or military endeavours. Nevertheless, statue attacks might decline if, for more important social reasons, the New Zealand Government better addresses the ongoing consequences of colonialism and minimises entanglements with foreign wars. An example is the New Zealand Government processes in place for addressing historical injustices against Māori, such as the Waitangi Tribunal process.

More specifically, there is a case for new statues to better represent the current New Zealand population and so new ones of Māori, Pacific peoples, Asian peoples and women could all be considered. But alternatives to statues also exist that may have more public utility, for example naming more parks, playgrounds, buildings and other civil infrastructure after significant people from underrepresented groups.

Existing statues can also be provided with different contexts, or moved. Different contexts could be achieved by the addition of "alternate history" figures, or by explanatory information. If removal was decided upon, controversial statues could be the first to go - potentially with associated public ceremonies to "take the power out" of them [1]. The range of removal options include relocation to statue parks or cemeteries where status can be better contextualised (eg, the statue subject's violent/imperialist/racist activities detailed in accompanying information boards). But controversial statues could also be completely removed from the public sphere to museum facilities (even to storerooms where they are only available to historical researchers). This may be the appropriate action for a number of New Zealand statues eg, for Captain Hamilton, George Grey and John Ballance (all active in colonial wars); Edward Wakefield (a colonialist who was also imprisoned for child abduction); and Lord Auckland (a colonial figure involved in an invasion of Afghanistan, with his statue being imported to Auckland City when India wanted it removed).

In addition to the removal of controversial statues, there could also be retirement of some of those statues of European men who are of little historical relevance (eg, small town mayors). Some of these statues already show signs of neglect given the level of surface erosion and lichen encrustation (see Fig. S4 in Supporting Information). Indeed, there could be cost savings for society if such statues are removed and don't require expensive repairs (eg, see the Introduction for an example repair cost).

\section{Conclusions}

There is quantitative and qualitative evidence that attacks on some of these statues in New Zealand may reflect the role of statue subjects in past and ongoing social injustices and in 
militarism. Furthermore, the demography of the statue subjects in this country represent historical and current social power relationships - with under-representation of women and nonEuropean ethnic groups.

Acknowledgements: We thank Ashley Wilson and Catherine Ferguson for assistance with data collection.

Funding: There was no funding source for this study.

Competing interests: None declared.

\section{References}

1. Mervosh S. What should happen to Confederate statues? A city auctions one for $\$ 1.4$ million. New York Times 2019;(22 June). https://www.nytimes.com/2019/06/22/us/confederate-statues-dallas-nashville.html.

2. Associated Press. San Francisco to remove statue deemed racist and demeaning to indigenous groups. TV1 News (14 September). 2018. https://www.tvnz.co.nz/onenews/world/san-francisco-remove-statue-deemed-racist-and-demeaning-indigenousgroups.

3. Bellafante G. Statue of doctor who did slave experiments is exiled. Its ideas are not. New York Times 2018:(18 April). https://www.nytimes.com/2018/04/18/nyregion/simssculpture-green-wood-cemetery.html.

4. Kelly K. Decapitating Lenin statues is the hottest new trend in Ukraine. Vice (26 May 2017). https://www.vice.com/en_nz/article/nejpwx/decapitating-lenin-statues-is-thehottest-new-trend-in-ukraine.

5. Dublin City Council. Statue of King William III. Dublin, February 2019. https://www.dublincity.ie/story/statue-king-william-iii

6. Taylor A. The statue of a wartime sex slave outside Japan's embassy in South Korea could be a problem. The Washington Post 2015 (29 December). https://www.washingtonpost.com/news/worldviews/wp/2015/12/29/the-statue-of-awartime-sex-slave-outside-japans-embassy-in-south-korea-could-be-a-problem/.

7. BBC World News. Osaka cuts San Francisco ties over 'comfort women' statue. BBC World News 2018:(4 October). https://www.bbc.com/news/world-us-canada-45747803.

8. Marusic S-J. Macedonia to rename divisive statues that irked Greece. BalkanInsight 2018(15 June). https://balkaninsight.com/2018/06/15/divisive-skopje-2014-landmarksfind-new-purpose-06-14-2018/.

9. Wikipedia. Bronze Soldier of Tallinn. [Version last edited on 6 May 2019]. https://en.wikipedia.org/wiki/Bronze_Soldier_of_Tallinn.

10. BBC News. Indian farmers fume at $\$ 430 \mathrm{~m}$ cost of Gujarat statue. BBC News 2018:(28 October) https://www.bbc.com/news/world-asia-india-45978120.

11. Prasad I. Why giant statues of Hindu gods and leaders are making Muslims in India nervous. The Conversation (11 April 2019). http://theconversation.com/why-giantstatues-of-hindu-gods-and-leaders-are-making-muslims-in-india-nervous-112818.

12. Ward A. An Unsettled History: Treaty Claims in New Zealand Today. Wellington: Bridget Williams Books, 1999. 
13. Brookes B. A history of New Zealand women. Wellington: Bridget Williams Books, 2016.

14. Statistics New Zealand. 2013 Census QuickStats about culture and identity. Statistics New Zealand, 2014. http://archive.stats.govt.nz/Census/2013-census/profile-andsummary-reports/quickstats-culture-identity.aspx.

15. Harvie W. Christchurch's Robert Falcon Scott statue gets base isolation. Stuff 2017:(6 October ). https://i.stuff.co.nz/the-press/business/the-rebuild/97546869/christchurchsrobert-falcon-scott-statue-gets-base-isolation.

16. Wikipedia. New Zealand's Top 100 History Makers. https://en.m.wikipedia.org/wiki/New_Zealand\%27s_Top_100_History_Makers (accessed 21 September 2018).

17. Henzell J. Religious eccentric wins right of appeal. The Press. 6 June, 2007.

18. Hinchliffe J. Pink paint poured on Captain Cook's statue on eve of Australia Day. The Age 2018;(25 January). https://www.theage.com.au/national/victoria/pink-paint-pouredon-captain-cook-s-statue-on-eve-of-australia-day-20180125-p4yyvg.html.

19. Manda S. George V statue vandalised again. Independent Online 2015;(30 March). https://www.iol.co.za/news/south-africa/kwazulu-natal/george-v-statue-vandalised-again1838807.

20. Schrader B. Public protest - Sit-ins and occupations. Te Ara - the Encyclopedia of New Zealand, http://www.TeAra.govt.nz/en/photograph/35094/ballance-beheaded (accessed 2 September 2017).

21. Stocker M. "Director of the Canoe": The Auckland Statue of Sir George Grey. Melbourne Art Journal. 2009;11-12:57-8.

22. Hawke's Bay Tourism. Nga Pou o Heretaunga. https://www.hawkesbaynz.com/visit/us/nga-pou-o-heretaunga [Accessed 9 November 2019]. 


\section{Supporting Information}

\section{Additional methods details}

Search strategy for statues and information on them: No detailed list of existing statues in New Zealand could be identified, so we used the following sources to help identify them: books on New Zealand sculpture [1] [2], and memorials [3]; a list of memorials and monuments in a New Zealand Encyclopaedia [4]; a city-specific sculpture websites [5] [6], and an international statue website [7].

To identify additional statues we conducted searches in Google Images using the following search terms (all conducted in September 2018):

- "Statue and Zealand and [city name]" for all New Zealand cities (ie, urban centres with a population of 50,000+ [ 100 images each]): Auckland, Wellington, Christchurch, Hamilton, Tauranga, Napier-Hastings, Dunedin, Palmerston North, Nelson, Rotorua, Whangarei, New Plymouth, and Invercargill.

- "Statue and Zealand and [name]" for a list of 100 famous New Zealanders ranked out of 430 notable people by a panel on a television series on famous New Zealanders [8].

- "Statue and Zealand" (for all 100+ images returned)

- "Bust and Zealand" (for all 100+ images returned)

- "Bas relief" and Zealand (for all images returned)

- "Zealand statue unveiled" (for all images returned)

After the above, further searches were made using "Papers Past" [9], which has a national repository for all New Zealand newspaper issues published from 1/1/1839 to 31/12/1949. Search terms included the exact phrase of "statue unveiled" and "statue unveiling" (and similarly for "bust"). But also to identify less well documented statues of Māori, we also searched using "Maori and statue". Google Image searches and the Papers Past searches were terminated when yielding under one new statue for 30 minutes of search time with each respective search engine. For additional context on the statues, we searched Google Scholar for scholarly literature relating to statues in New Zealand (eg, [3] [10-14]).

Evaluating search strategy sensitivity: We evaluated our search strategy by conducting additional searching for all the statues in New Zealand's largest city: Auckland. This involved searches by a different co-author (the last named author) from the original searches detailed above (by the first author). The searches involved some of the same, but also additional elements to the above searches:

- Google Images, using all of: 'Auckland' 'Zealand' 'statue OR bust'

- The largest newspaper based in Auckland (the NZ Herald), using: 'statue' 'Zealand' (first 15 pages); and 'statue' 'Auckland' (all 20 pages)

- The Factiva Database for "NZ publications" and "all dates" with the terms:

○ 'statue and Auckland and unveiling' (all 69 returns)

○ 'statue and Zealand and unveiling' (all 100 returns)

- "Papers Past", using: 'Auckland' and 'statue' 
This extra strategy identified no new statues (out of the 16 statues in Auckland), giving us some confidence that the original strategy was fairly sensitive. Furthermore, Papers Past appeared to typically have multiple newspaper items that documented the same statue unveiling - suggesting that this was a relatively sensitive mechanism for statue identification. Nevertheless, subsequent to the original searches, we did incidentally locate six additional statues as a result of both further internet searches $(n=3)$, and field work $(n=3)$ up to the last inclusion date (13 April 2019 when the statue of Lithgow was unveiled). This suggested our initial search strategy was no more than $94 \%$ sensitive $(116 / 123)$.

Statue attack data: Identifying a statue as per the above search strategies frequently revealed historical information about attacks on the statue. But we also performed additional searches in Papers Past and with search terms including the words: statue and vandalism; statue and paint and damage; statue decapitation. Similarly for Google searches: Zealand and statue and decapitation/graffiti/stolen/broken.

Field data: Site visits to all the statues that were still outdoors were conducted between September 2018 and August 2019. Photographs were taken of the setting and from all sides of the statues (including of any associated plaques or information boards). In particular, evidence for past and current injuries (including attacks with paint) were closely looked for eg, in nostrils and ear canals - where removal of paint is more difficult.

Data coding and analysis: Data from internet searches and field visits were collated in an Excel file and analysed. The denominator used was for all statues unveiled at any time up to the last inclusion date (13 April 2019). This therefore included all those subsequently destroyed $(n=3)$, stolen $(n=1)$, or moved from outdoors and into interior settings $(n=14)$. When a stolen statue was replaced $(n=1)$ this was included as a new statue in the denominator.

We defined statue attacks as being where there was documentation of a historical attack (eg, in Papers Past or in online media reports) or from our field observations of obvious repairs or selected missing body parts (eg, noses), paint remnants, or graffiti. Not included were minor embellishments such as the addition of lipstick to the statues' lips, application of chewing gum, clothing added to the statue or having traffic cones placed on their heads. We also excluded damage that was unintentional eg, the multiple statues damaged by the 2011 Christchurch earthquake and statues destroyed by fungal infection (eg, George Grey in Greytown). 
Table S1: Reasons for excluding certain types of statues with examples

\begin{tabular}{|c|c|}
\hline Reason for exclusion & Selected example/s \\
\hline $\begin{array}{l}\text { Subject of the statue did not } \\
\text { meet the following three criteria: } \\
1 . \quad \text { an actual person } \\
2 \text { a non-foundational } \\
\text { religious figure } \\
\text { 3. part of the modern era } \\
\text { (from Tasman's first visit in } \\
\text { 1642AD) }\end{array}$ & $\begin{array}{l}\text { - Generic figures: eg, many generic soldier figures on war } \\
\text { memorials around NZ (eg, "Trooper Mackenzie" (Fairlie)); "Art Deco } \\
\text { Woman" (Napier); "Barry" (Katikati); Rangatira (Waihi); the statue at the } \\
\text { grave of Harry Holland (Wellington) which is a figurative one of a young } \\
\text { man. } \\
\text { - } \quad \text { Foundational religious figures: Virgin Mary, Jesus. } \\
\text { - } \quad \text { Pre-European ancestors of Māori: the } 18 \text { pou with } \\
\text { representations of Māori ancestors: "Ngā Pou O Heretaunga" (Hastings); } \\
\text { Kupe (group statue in Wellington), Kupe (Whāingaroa). } \\
\text { - } \quad \text { Fictional characters from books eg, Peter Pan (Dunedin). }\end{array}$ \\
\hline $\begin{array}{l}\text { Statue was only ever on } \\
\text { temporary display outdoors }\end{array}$ & $\begin{array}{l}\text { Various works by the artist Sam Mahon (eg, of Catherine Sintenie, Nick } \\
\text { Smith); Dorothy Theomin (bust, Dunedin). }\end{array}$ \\
\hline $\begin{array}{l}\text { Statue is not in a public } \\
\text { setting (eg, in a marae, } \\
\text { cemetery or urupā [Māori } \\
\text { cemetery], or school). We made } \\
\text { this criteria to ensure that the } \\
\text { statues were likely to represent } \\
\text { a relatively public figure - and } \\
\text { not be for a person who was } \\
\text { significant just to their family, } \\
\text { family group, or iwi (tribe). }\end{array}$ & $\begin{array}{l}\text { Statues on marae/urupā (eg, of: Maui Pomare, Tangatahara, } \\
\text { King Mahuta, Pouawha Meihana, Henare Pohio). } \\
\text { - Statues in school grounds: Captain James Cook, James (Jack) } \\
\text { Lovelock, St John Baptist De La Salle. } \\
\text { - Statue in a fenced stadium (ie, not routinely accessible to the } \\
\text { public): Arthur Lydiard. } \\
\text { Statues on private land: Richard Nixon (Nelson), Tommy } \\
\text { Solomon (Chatham Islands), Mark Twain (Matakana), Edwin Mitchelson } \\
\text { (Auckland), Edmund Hillary (Mt Cook - within hotel premises). } \\
\text { - Statues in cemeteries: Harry Holland (Wellington). }\end{array}$ \\
\hline $\begin{array}{l}\text { The main statue is to something } \\
\text { else with the person being } \\
\text { secondary }\end{array}$ & $\begin{array}{l}\text { The jockey (Jim Pike) on the statue of the racehorse Phar Lap (which is } \\
\text { the primary statue). }\end{array}$ \\
\hline $\begin{array}{l}\text { Statue has always been located } \\
\text { indoors }\end{array}$ & $\begin{array}{l}\text { Kate Sheppard (Wellington); Seddon (bust in Wellington); Tupai (bust in } \\
\text { Wellington); Kiri Te Kanawa (Auckland); Te Heuheu Tukino IV } \\
\text { (Horonuku) (National Park, Mt Ruapehu). }\end{array}$ \\
\hline $\begin{array}{l}\text { Statue is clearly miniaturised } \\
\text { (ie, half-sized or less in height) }\end{array}$ & Dick Henderson with wounded solider on a donkey (Wellington). \\
\hline $\begin{array}{l}\text { The statue has no three } \\
\text { dimensionality (in contrast to a } \\
\text { bas relief) }\end{array}$ & Caesar Roose (Hamilton) \\
\hline $\begin{array}{l}\text { Bas relief is not full length; or is } \\
\text { only a component of a larger } \\
\text { statue }\end{array}$ & Jean Batten (Rotorua), Austen Deans (Mt Peel) \\
\hline $\begin{array}{l}\text { The work is limited to being a } \\
\text { carved head on a building }\end{array}$ & Various members of Royalty (eg, High Court Building, Auckland) \\
\hline
\end{tabular}


Table S2: Full list of the 123 outdoor statues in public places identified in New Zealand (ordered by surname), their location and presence of militaristic elements (uniform, firearm, sword etc)

\begin{tabular}{|c|c|c|}
\hline Surname, first name & Location and notes & $\begin{array}{l}\text { Militaristic } \\
\text { element on } \\
\text { statue }\end{array}$ \\
\hline Alley, Rewi & Auckland & \\
\hline Atkinson, Henry & Auckland & \\
\hline Auckland, Lord (George Eden) & Auckland & \\
\hline Ballance, John & Wellington & \\
\hline Ballance, John & Whanganui (outside Council Buildings) & \\
\hline Ballance, John & $\begin{array}{l}\text { Whanganui (statue attacked and destroyed, } \\
\text { Moutoa Gardens) }\end{array}$ & \\
\hline Batten, Jean & Auckland & \\
\hline Beavon, Professor Sir Donald Ward & Christchurch & \\
\hline Bourne, Possum & Auckland (Pukekohe) & \\
\hline Burns, Robert (Robbie) & Auckland & \\
\hline Burns, Robert (Robbie) & Dunedin & \\
\hline Burns, Robert (Robbie) & Hokitika (see Fig. 2, main text) & \\
\hline Burns, Robert (Robbie) & Timaru & \\
\hline Byrd, Rear Admiral Richard Evelyn & Dunedin & \\
\hline Byrd, Rear Admiral Richard Evelyn & Wellington & \\
\hline Cain, Captain Henry & Timaru & \\
\hline Campbell, John Logan & Auckland & \\
\hline Carrington, Frederic & New Plymouth & \\
\hline Carter, Charles Rooking & Carterton & \\
\hline Colvin, James & Westport & \\
\hline Cook, Captain James & $\begin{array}{l}\text { Auckland (this was originally outside a brewery } \\
\text { but has since been moved indoors) }\end{array}$ & Yes \\
\hline Cook, Captain James & Christchurch & Yes \\
\hline Cook, Captain James & $\begin{array}{l}\text { Gisborne (was on Kaiti Hill but was moved to a } \\
\text { museum in 2019) }\end{array}$ & Yes \\
\hline Cook, Captain James & Gisborne (river mouth location) & Yes \\
\hline Cook, Captain James & Marton & Yes \\
\hline Cruickshank, Dr Margaret & Waimate & \\
\hline Crumen, Barrett (“Russian Jack”) & Masterton & \\
\hline Daldy, Amey & Christchurch (temporarily in storage) & \\
\hline Dickson, Frank & Christchurch (temporarily in storage) & \\
\hline Elworthy, Rt Hon Lord (Samuel Charles) & Timaru & \\
\hline Fantham, A.A. & Hawera (Taranaki) & \\
\hline Fitzgerald, James Edward & Christchurch & \\
\hline Fitzsimmons, Bob & Timaru & \\
\hline Fraser, Peter & Wellington & \\
\hline
\end{tabular}




\begin{tabular}{|c|c|c|}
\hline Surname, first name & Location and notes & $\begin{array}{l}\text { Militaristic } \\
\text { element on } \\
\text { statue }\end{array}$ \\
\hline Freyberg, Lord Bernard & Auckland & Yes \\
\hline Gallaher, Dave & Auckland & \\
\hline Gandhi, Mahatma & Wellington & \\
\hline George V, King & $\begin{array}{l}\text { Matakana (town near Warkworth) (see Fig. } 2 \\
\text { main text) }\end{array}$ & Yes \\
\hline George V, King & Rotorua & Yes \\
\hline Godley, John Robert & Christchurch & \\
\hline Grant, John (VC) & Hawera (Taranaki) & Yes \\
\hline Grey, Sir George & Auckland & \\
\hline Grey, Sir George & Greytown (was destroyed by fungal infection) & \\
\hline Grigg, John & Ashburton & \\
\hline Hadlee, Sir Richard John & Christchurch (temporarily in storage) & \\
\hline Hamilton, Captain John Fane Charles & Hamilton & Yes \\
\hline Herd, David & Blenheim & \\
\hline Hillary, Sir Edmund & Orewa & \\
\hline Holyoake, Sir Keith & Wellington & \\
\hline Isaac, Lady Diana & Christchurch (temporarily in storage) & \\
\hline Jellicoe, Earl John & Invercargill (see Fig. S1) & Yes \\
\hline Joll, Thomas Langdon & Okaiawa (Taranaki) & \\
\hline Jones, Michael & Auckland (see Fig. S2) & \\
\hline Jordan, Canon Charles & Tauranga & Yes \\
\hline Kipling, Rudyard & Christchurch & \\
\hline Kitchener, Field Marshal Horatio Herbert & Auckland (destroyed in an attack) & Yes \\
\hline Kitchener, Field Marshal Horatio Herbert & Invercargill & Yes \\
\hline Laurent, Henry (VC) & Hawera (Taranaki) & Yes \\
\hline Lindauer, Gottfried & Woodville & \\
\hline Lithgow, Alex & Invercargill & \\
\hline Little, Dr Charles & Waikari (North Canterbury) (see Fig. S4) & \\
\hline Locke, Elsie & Christchurch (temporarily in storage) & \\
\hline Luney, Charles & Christchurch (temporarily in storage) & \\
\hline Macandrew, James & Dunedin & \\
\hline Mackenzie, James & Fairlie (South Canterbury) & \\
\hline Mahy, Margaret & Christchurch (temporarily in storage) & \\
\hline Malfroy, Camille & Rotorua & \\
\hline Malone, Lieutenant Colonel William & Stratford (Taranaki) & Yes \\
\hline Mangakāhia, Meri Te Tai & Christchurch (part of suffragette bas-relief) & \\
\hline Mansfield, Katherine & Wellington & \\
\hline Masters, Joseph & Masterton & \\
\hline
\end{tabular}




\begin{tabular}{|c|c|c|}
\hline Surname, first name & Location and notes & $\begin{array}{l}\text { Militaristic } \\
\text { element on } \\
\text { statue }\end{array}$ \\
\hline McKinnon, Quintin & Te Anau & \\
\hline Meads, Sir Colin & Te Kuiti & \\
\hline Meryon, Charles & Akaroa & \\
\hline Monro, Charles & Palmerston North & \\
\hline Moore-Jones, Horace & Hamilton & Yes \\
\hline Moorhouse, William Sefton & Christchurch & \\
\hline Morison, Harriet & Christchurch (part of suffragette bas-relief) & \\
\hline Munro, Burt & Invercargill & \\
\hline Nelson, William & Hastings & \\
\hline Nicholas, Henry James (VC) & Christchurch & Yes \\
\hline Nicol, Helen & Christchurch (part of suffragette bas-relief) & \\
\hline O’Regan, Sir Tipene & Christchurch (temporarily in storage) & \\
\hline Plimmer, John & Wellington & \\
\hline Rees, William Gilbert & Queenstown & \\
\hline Robinson, Sir Dove-Myer & Auckland & \\
\hline Rolleston, William & Christchurch & \\
\hline Ruskin, John & Christchurch & \\
\hline Russell, Sir Andrew & Hastings & Yes \\
\hline Rutherford, Ernest & Brightwater (Nelson) & \\
\hline Scott, Sir Robert Falcon & Christchurch & \\
\hline Seddon, Richard (Dick) & Hokitika & \\
\hline Seddon, Richard (Dick) & Wellington & \\
\hline Sheppard, Kate & Christchurch (part of suffragette bas-relief) & \\
\hline Snell, Sir Peter & Opunake (Taranaki) & \\
\hline Snell, Sir Peter & Whanganui & \\
\hline Stewart, Sir Robertson & Christchurch (temporarily in storage) & \\
\hline Stuart, Rev Dr Donald & Dunedin & \\
\hline Sutton, Bill & Christchurch (temporarily in storage) & \\
\hline Tait, Admiral Sir Gordon & Timaru (stolen) & \\
\hline Tait, Admiral Sir Gordon & Timaru (replacement of stolen one) & \\
\hline Tait, Sir Angus & Christchurch (temporarily in storage) & \\
\hline Tasman, Abel & Nelson (see Fig. 2, main text) & Yes \\
\hline Te Awe Awe, Te Peeti & Palmerston North & Yes \\
\hline Te Keepa Te Rangihiwinui & Whanganui & Yes \\
\hline Te Rauparaha & Otaki & \\
\hline Te Wainohu, Henare Wepiha & Wairoa & Yes \\
\hline Thomson, John Turnbull & Ranfurly (Otago) & \\
\hline Upham, Charles (VC) & Amberley (North Canterbury) & Yes \\
\hline
\end{tabular}




\begin{tabular}{|c|c|c|}
\hline Surname, first name & Location and notes & $\begin{array}{l}\text { Militaristic } \\
\text { element on } \\
\text { statue }\end{array}$ \\
\hline Victoria, Queen & Auckland & \\
\hline Victoria, Queen & Christchurch & \\
\hline Victoria, Queen & Dunedin (see Fig. 2, main text) & Yes \\
\hline Victoria, Queen & Wellington & \\
\hline Wakefield, Edward Gibbon & Wellington & \\
\hline Walker, Sir John & Auckland & \\
\hline Ward, Sir Joseph & Bluff (Southland) & \\
\hline Warren, Sir Miles & Christchurch (temporarily in storage) & \\
\hline Wellington, Duke of & Wellington & \\
\hline Wells, Ada & Christchurch (part of suffragette bas-relief) & \\
\hline Whakarua, Herewini & Whanganui (see Fig. S3) & Yes \\
\hline Worsley, Frank & Akaroa & \\
\hline Wylie, Fred W. & Rotorua & Yes \\
\hline Young, Nicholas (“Young Nick”) & Gisborne & \\
\hline
\end{tabular}


Table S3. A priori classification of statue subjects in terms of colonialism/harm to Māori, being important military decision-makers, and having any association with the military

\begin{tabular}{|c|c|c|c|c|c|}
\hline $\begin{array}{l}\text { Name of the } \\
\text { statue subject }\end{array}$ & Reason for fame & $\begin{array}{c}\text { Involved } \\
\text { in } \\
\text { colonial- } \\
\text { ism in NZ } \\
\text { or } \\
\text { specific } \\
\text { harm to } \\
\text { Māori }\end{array}$ & $\begin{array}{c}\text { Military } \\
\text { decision- } \\
\text { maker } \\
\text { (Commiss } \\
\text {-ioned } \\
\text { Officer } \\
\text { rank* or } \\
\text { political } \\
\text { leader) }\end{array}$ & $\begin{array}{l}\text { Any } \\
\text { involve } \\
\text { ment } \\
\text { with the } \\
\text { military }\end{array}$ & Notes \\
\hline Auckland, Lord & $\begin{array}{l}\text { Auckland City } \\
\text { named after him; } \\
\text { Colonial } \\
\text { Administrator \& } \\
\text { politician }\end{array}$ & No & Yes & Yes & $\begin{array}{l}\text { He was a decision-maker involved in an invasion of Afghanistan by British military } \\
\text { forces (the First Anglo-Afghan War, 1838-1842). We acknowledge that this was an } \\
\text { event distant in time and place from NZ - but it was still a major military action. }\end{array}$ \\
\hline Ballance, John & $\begin{array}{l}\text { Prime Minister of } \\
\text { NZ }\end{array}$ & Yes & No & Yes & $\begin{array}{l}\text { He was involved in the NZ Wars [12], which were land wars between colonial forces } \\
\text { and Māori. While he "saw some limited action with the Wanganui Cavalry } \\
\text { Volunteers" [15], his military rank is assumed to have been low. Although he } \\
\text { became Minister of Defence and Prime Minister, these were after the time of the NZ } \\
\text { Wars. }\end{array}$ \\
\hline $\begin{array}{l}\text { Byrd, Rear } \\
\text { Admiral }\end{array}$ & Explorer & No & Yes & Yes & $\begin{array}{l}\text { He was involved in the First (WW1) and Second (WW2) World Wars and was then } \\
\text { as an explorer as a US naval officer. He achieved the rank of Rear Admiral. } \\
\text { However, his main fame was for exploration. }\end{array}$ \\
\hline $\begin{array}{l}\text { Cook, James } \\
\text { [Captain] }\end{array}$ & Explorer & Yes & Yes & Yes & $\begin{array}{l}\text { He was the expedition leader when some local Māori were killed by his crew at the } \\
\text { time of his visit to Gisborne in } 1769 \text {. This European contact also symbolises the start } \\
\text { of the loss of Māori land to Europeans in the subsequent century and longer. } \\
\text { After being a Captain in the Royal Navy, his rank rose to that of a Commander and } \\
\text { then a "Post-captain". }\end{array}$ \\
\hline $\begin{array}{l}\text { Elworthy, Rt Hon } \\
\text { Lord (Samuel } \\
\text { Charles) }\end{array}$ & $\begin{array}{l}\text { Military leader in } \\
\text { WW2 }\end{array}$ & No & Yes & Yes & $\begin{array}{l}\text { He was a Commander in the Air Force in WW2, and subsequently became Chief of } \\
\text { the Defence Staff [16]. }\end{array}$ \\
\hline Fraser, Peter & $\begin{array}{l}\text { Prime Minister of } \\
\text { NZ }\end{array}$ & No & Yes & Yes & $\begin{array}{l}\text { He was the key political figure in NZ's contribution to WW2 ie, from } 1939 \text { "Fraser } \\
\text { assumed the direction of the New Zealand war effort" [17]. His government also } \\
\text { imposed harsh penalties on war objectors during and after WW2 [18]. However, he } \\
\text { was jailed for anti-conscription activity in WW1 [18]. }\end{array}$ \\
\hline $\begin{array}{l}\text { Freyberg, Lord } \\
\text { Bernard }\end{array}$ & $\begin{array}{l}\text { Military } \\
\text { leader/Governor } \\
\text { General }\end{array}$ & No & Yes & Yes & $\begin{array}{l}\text { He was a professional soldier for most of his working life. He participated in WW1 } \\
\text { and WW2 and in the latter was a Lieutenant General [16]. }\end{array}$ \\
\hline Gallaher, Dave & Top rugby player & No & No & Yes & $\begin{array}{l}\text { He was involved in the South African War and WW1. He achieved the rank of } \\
\text { sergeant [16]. But his main fame was as a rugby player. }\end{array}$ \\
\hline
\end{tabular}




\begin{tabular}{|c|c|c|c|c|c|}
\hline $\begin{array}{l}\text { Name of the } \\
\text { statue subject }\end{array}$ & Reason for fame & $\begin{array}{c}\text { Involved } \\
\text { in } \\
\text { colonial- } \\
\text { ism in NZ } \\
\text { or } \\
\text { specific } \\
\text { harm to } \\
\text { Māori }\end{array}$ & $\begin{array}{l}\text { Military } \\
\text { decision- } \\
\text { maker } \\
\text { (Commiss } \\
\text {-ioned } \\
\text { Officer } \\
\text { rank* or } \\
\text { political } \\
\text { leader) }\end{array}$ & $\begin{array}{c}\text { Any } \\
\text { involve } \\
\text { ment } \\
\text { with the } \\
\text { military }\end{array}$ & Notes \\
\hline George V [King] & $\begin{array}{l}\text { King of the UK } \\
\text { and the British } \\
\text { Dominions } \\
\text { (including NZ) }\end{array}$ & Yes & Yes & Yes & $\begin{array}{l}\text { He was King from } 1910 \text { to } 1936 \text {, a time when the British Crown substantially ignored } \\
\text { its Treaty of Waitangi obligations. His deficient role is given emphasis as he (as the } \\
\text { Crown) was the direct Treaty partner with Māori in NZ. Indeed, during his reign in } \\
1914 \text { and } 1924 \text { deputations of Māori travelled to England to take petitions based on } \\
\text { the Treaty to the British monarch and the British Government [19]. He had a } \\
\text { powerful figurehead role during WW1 and he was very active in visiting the troops. } \\
\text { In terms of military ranks for NZ, the highest ranks are taken by royalty eg, the } \\
\text { admiral of the fleet (navy) and field marshal (army). }\end{array}$ \\
\hline Grant, John & $\begin{array}{l}\text { VC winner in } \\
\text { WW1 }\end{array}$ & No & Yes & Yes & He was a soldier in WW1 and reached the rank of 2nd Lieutenant [16]. \\
\hline Grey, George [Sir] & $\begin{array}{l}\text { Governor of NZ; } \\
\text { Premier of NZ }\end{array}$ & Yes & Yes & Yes & $\begin{array}{l}\text { He was involved in the NZ Wars where Māori land was taken [10]. His position as } \\
\text { Governor of New Zealand, although a mainly political one, can be regarded as } \\
\text { equivalent to a high ranking military one during the time of the NZ Wars. }\end{array}$ \\
\hline $\begin{array}{l}\text { Hamilton, John } \\
\text { [Captain] }\end{array}$ & $\begin{array}{l}\text { Military leader/ } \\
\text { City of Hamilton } \\
\text { named after him }\end{array}$ & Yes & Yes & Yes & $\begin{array}{l}\text { He was involved in the Battle of Gate Pā (NZ Wars) where Māori were killed. } \\
\text { His highest rank was as a Commander in the navy. }\end{array}$ \\
\hline Holyoake, Keith & Prime Minister & No & Yes & Yes & $\begin{array}{l}\text { He was Prime Minister of NZ when the Government sent military personnel to the } \\
\text { Vietnam war in the 1960s [20]. }\end{array}$ \\
\hline $\begin{array}{l}\text { Jellicoe, John } \\
\text { Rushworth [Earl] }\end{array}$ & $\begin{array}{l}\text { Military leader and } \\
\text { Governor General } \\
\text { of NZ }\end{array}$ & No & Yes & Yes & He was an Admiral of the Fleet in WW1 (British Navy). \\
\hline $\begin{array}{l}\text { Kitchener, Horatio } \\
\text { Herbert [Field } \\
\text { Marshal] }\end{array}$ & $\begin{array}{l}\text { Military leader in } \\
\text { WW1 }\end{array}$ & No & Yes & Yes & $\begin{array}{l}\text { He was a Field Marshal in WW1 (British Army). He was a key figure in setting up } \\
\text { concentration camps in the South African War. }\end{array}$ \\
\hline Laurent, Henry & $\begin{array}{l}\text { VC winner in } \\
\text { WW1 }\end{array}$ & No & Yes & Yes & He was a soldier in WW1. He reached the rank of Lieutenant Colonel in WW2 [16]. \\
\hline Malone, William & $\begin{array}{l}\text { Military leader/ } \\
\text { war hero }\end{array}$ & No & Yes & Yes & He was an officer in WW1. He reached the rank of Lieutenant Colonel [16]. \\
\hline $\begin{array}{l}\text { Moore-Jones, } \\
\text { Horace }\end{array}$ & Soldier artist & No & No & Yes & $\begin{array}{l}\text { He was involved in the South African War and WW1. He achieved the rank of } \\
\text { sapper [16]. }\end{array}$ \\
\hline
\end{tabular}




\begin{tabular}{|c|c|c|c|c|c|}
\hline $\begin{array}{l}\text { Name of the } \\
\text { statue subject }\end{array}$ & Reason for fame & $\begin{array}{c}\text { Involved } \\
\text { in } \\
\text { colonial- } \\
\text { ism in NZ } \\
\text { or } \\
\text { specific } \\
\text { harm to } \\
\text { Māori }\end{array}$ & $\begin{array}{c}\text { Military } \\
\text { decision- } \\
\text { maker } \\
\text { (Commiss } \\
\text {-ioned } \\
\text { Officer } \\
\text { rank* or } \\
\text { political } \\
\text { leader) }\end{array}$ & $\begin{array}{c}\text { Any } \\
\text { involve } \\
\text { ment } \\
\text { with the } \\
\text { military }\end{array}$ & Notes \\
\hline $\begin{array}{l}\text { Nicholas, Henry } \\
\text { James }\end{array}$ & $\begin{array}{l}\text { VC winner in } \\
\text { WW1 }\end{array}$ & No & No & Yes & He was an soldier in WW1 and he reached the rank of Sergeant [16]. \\
\hline $\begin{array}{l}\text { Russell, Sir } \\
\text { Andrew }\end{array}$ & Military leader & No & Yes & Yes & He was an officer in WW1 and he reached the rank of Major General [16]. \\
\hline $\begin{array}{l}\text { Scott, Sir Robert } \\
\text { Falcon }\end{array}$ & Explorer & No & Yes & Yes & $\begin{array}{l}\text { He achieved the high military ranking of "Naval Assistant to the Second Sea Lord". } \\
\text { However, his main fame has been as an explorer. }\end{array}$ \\
\hline Seddon, Richard & Prime Minister & No & Yes & Yes & $\begin{array}{l}\text { He was the Prime Minister throughout the period of the South African War. Indeed, } \\
\text { "he also attracted much publicity for his outspokenness about the South African war: } \\
\text { he visited South Africa in } 1902 \text { at General Kitchener's invitation. He was increasingly } \\
\text { ready to arouse and exploit popular nationalism" [21]. }\end{array}$ \\
\hline $\begin{array}{l}\text { Tait, Gordon } \\
\text { [Admiral Sir] }\end{array}$ & Military leader & No & Yes & Yes & He was an Admiral in WW2 (British Navy). \\
\hline Tasman, Abel & $\begin{array}{l}\text { Explorer and } \\
\text { navigator }\end{array}$ & Yes & Yes & Yes & $\begin{array}{l}\text { He was the leader when Māori were killed in an encounter with his ships. } \\
\text { His highest rank was a Commander. }\end{array}$ \\
\hline $\begin{array}{l}\text { Te Awe Awe, Te } \\
\text { Peeti }\end{array}$ & $\begin{array}{l}\text { Māori Chief } \\
\text { involved in the NZ } \\
\text { Wars and also } \\
\text { land disputes }\end{array}$ & Yes & Yes & Yes & $\begin{array}{l}\text { He was part of an alliance with the Crown in the Taranaki Campaign in the NZ Wars } \\
\text { [22]. His military rank status was not identified in our literature search, but we } \\
\text { consider it likely to be at least officer level equivalency given his status as a chief. } \\
\text { He was also involved in land disputes with other Māori tribes [22]. }\end{array}$ \\
\hline $\begin{array}{l}\text { Te Keepa Te } \\
\text { Rangihiwinui }\end{array}$ & $\begin{array}{l}\text { Māori Chief } \\
\text { involved in the NZ } \\
\text { Wars }\end{array}$ & Yes & Yes & Yes & $\begin{array}{l}\text { He was a military leader in alliances with the Crown in the NZ Wars [23]. His highest } \\
\text { rank was Major. }\end{array}$ \\
\hline Te Rauparaha & $\begin{array}{l}\text { Māori } \\
\text { Chief/military } \\
\text { leader }\end{array}$ & Yes & Yes & Yes & $\begin{array}{l}\text { He was involved in the "Musket Wars". He can be considered to have been of a high } \\
\text { military rank given his military leadership of his tribe, Ngati Toa [24]. }\end{array}$ \\
\hline $\begin{array}{l}\text { Te Wainohu, Rev } \\
\text { Henare Wepiha }\end{array}$ & $\begin{array}{l}\text { Chaplain for } \\
\text { Pioneer Battalion } \\
\text { (WW1) }\end{array}$ & No & Yes & Yes & $\begin{array}{l}\text { He was involved in WW1 as a high ranking army chaplain (attained the rank of } \\
\text { Chaplain Class III (Major)) [16]. He was part of the first Māori unit to serve in WW1. }\end{array}$ \\
\hline Upham, Charles & $\begin{array}{l}\text { Military hero (two } \\
\text { Victoria Crosses) }\end{array}$ & No & Yes & Yes & He was a soldier in WW2, and he achieved the rank of Captain [16]. \\
\hline
\end{tabular}




\begin{tabular}{|c|c|c|c|c|c|}
\hline $\begin{array}{l}\text { Name of the } \\
\text { statue subject }\end{array}$ & Reason for fame & $\begin{array}{l}\text { Involved } \\
\text { in } \\
\text { colonial- } \\
\text { ism in NZ } \\
\text { or } \\
\text { specific } \\
\text { harm to } \\
\text { Māori }\end{array}$ & $\begin{array}{c}\text { Military } \\
\text { decision- } \\
\text { maker } \\
\text { (Commiss } \\
\text {-ioned } \\
\text { Officer } \\
\text { rank* or } \\
\text { political } \\
\text { leader) }\end{array}$ & $\begin{array}{c}\text { Any } \\
\text { involve } \\
\text { ment } \\
\text { with the } \\
\text { military }\end{array}$ & Notes \\
\hline Victoria, Queen & $\begin{array}{l}\text { Queen of the UK } \\
\text { and the British } \\
\text { Dominions } \\
\text { (including NZ) }\end{array}$ & Yes & Yes & Yes & $\begin{array}{l}\text { She was Queen and was symbolic of the British colonial empire. In particular, she } \\
\text { was Queen during the NZ Wars and during a period when the Treaty of Waitangi } \\
\text { was dishonoured by the Crown [25]. Her deficient role is given emphasis as she (as } \\
\text { the Crown) was the direct Treaty partner with Māori in NZ. Indeed, during her reign } \\
\text { in } 1882 \text { and } 1884 \text { deputations of Māori travelled to England to take petitions based } \\
\text { on the Treaty to the British monarch and the British Government [19]. See under } \\
\text { George V as per the military status of Royalty. }\end{array}$ \\
\hline $\begin{array}{l}\text { Wakefield, } \\
\text { Edward Gibbon }\end{array}$ & $\begin{array}{l}\text { A founder of the } \\
\text { European } \\
\text { colonisation of } \mathrm{NZ}\end{array}$ & Yes & No & No & $\begin{array}{l}\text { He was a strong promoter of colonisation of NZ and in general, with an actual } \\
\text { "colonisation theory" [26]. Another aspect of his history was that he was imprisoned } \\
\text { (in England) for abducting 15-year-old schoolgirl [26]. }\end{array}$ \\
\hline Ward, Joseph & $\begin{array}{l}\text { Prime Minister of } \\
\text { NZ }\end{array}$ & No & Yes & Yes & $\begin{array}{l}\text { He was a key political figure in NZ's contribution to WW1 as co-leader of the } \\
\text { wartime coalition government between } 1915 \text { and } 1919 \text { [27]. }\end{array}$ \\
\hline $\begin{array}{l}\text { Wellington, [Duke } \\
\text { of] }\end{array}$ & $\begin{array}{l}\text { Military leader and } \\
\text { a NZ city named } \\
\text { after him }\end{array}$ & No & Yes & Yes & $\begin{array}{l}\text { He was involved as a leader in European warfare (Battle of Waterloo in 1815). We } \\
\text { acknowledge that this was an event distant in time and place from NZ - but it was } \\
\text { still a major military action. }\end{array}$ \\
\hline $\begin{array}{l}\text { Whakarua, } \\
\text { Herewini } \\
\text { (Whanganui) }\end{array}$ & $\begin{array}{l}\text { Representative of } \\
\text { Māori soldiers } \\
\text { from a community }\end{array}$ & No & No & Yes & $\begin{array}{l}\text { He was a soldier in WW1 who attained the rank of Sergeant-Major (ie, not a } \\
\text { Commissioned Officer) [16]. }\end{array}$ \\
\hline Worsley, Frank & Explorer & No & Yes & Yes & $\begin{array}{l}\text { He was involved in WW1 and WW2 and he achieved the rank of Lieutenant } \\
\text { Commander (navy) [16]. He has been known principally as an expert sailor and as } \\
\text { an explorer. }\end{array}$ \\
\hline Wylie, Fred W & $\begin{array}{l}\text { Bravery in military } \\
\text { action (South } \\
\text { Africa) }\end{array}$ & No & No & Yes & $\begin{array}{l}\text { He was a NZ soldier in the South African War. His highest rank was sergeant (ie, } \\
\text { not a Commissioned Officer) [16]. }\end{array}$ \\
\hline Young, Nick & $\begin{array}{l}\text { First person on } \\
\text { Cook's ship to } \\
\text { sight NZ }\end{array}$ & Yes & No & Yes & $\begin{array}{l}\text { He was part of Captain Cook's crew (part of the Royal Navy) when some local Māori } \\
\text { were killed by this crew at the time of Cook's visit to Gisborne. This European } \\
\text { contact also symbolises the start of the loss of Māori land to Europeans in the } \\
\text { subsequent century and longer. }\end{array}$ \\
\hline
\end{tabular}

* NZ Army ranks for Commissioned Officers (descending order): Field Marshal, Lieutenant General, Major General, Brigadier, Colonel, Lieutenant Colonel, Major, Captain, Lieutenant, Second Lieutenant, Officer Cadet. 
Table S4: Specific details on the 28 statues with intentional attacks (physical damage, paint or theft)

\begin{tabular}{|c|c|c|c|c|c|}
\hline $\begin{array}{l}\text { Name of the } \\
\text { memorialised } \\
\text { person } \\
\text { (locality) }\end{array}$ & $\begin{array}{l}\text { Reason for } \\
\text { fame }\end{array}$ & $\begin{array}{l}\text { Classified } \\
\text { as contro- } \\
\text { versial }\end{array}$ & $\begin{array}{l}\text { Nature of injuries/ } \\
\text { damage (dates) }\end{array}$ & $\begin{array}{l}\text { Possible reason/s } \\
\text { for damage }\end{array}$ & Outcomes \\
\hline $\begin{array}{l}\text { Atkinson, } \\
\text { Henry } \\
\text { (Auckland) }\end{array}$ & $\begin{array}{l}\text { Engineer/ } \\
\text { philanthropist }\end{array}$ & No & $\begin{array}{l}\text { Repeated thefts of } \\
\text { his nose (unknown } \\
\text { dates) }\end{array}$ & $\begin{array}{l}\text { Unknown - } \\
\text { possibly pranks }\end{array}$ & $\begin{array}{l}\text { Repaired and } \\
\text { moved from a hilltop } \\
\text { location to a more } \\
\text { urban location }\end{array}$ \\
\hline $\begin{array}{l}\text { Ballance, John } \\
\text { (Wellington) }\end{array}$ & $\begin{array}{l}\text { Prime Minister } \\
\text { of NZ }\end{array}$ & Yes & $\begin{array}{l}\text { Decapitation and the } \\
\text { words "Pākaitore is } \\
\text { Māori land" spray } \\
\text { painted on it (in } \\
\text { 1995) [12] }\end{array}$ & $\begin{array}{l}\text { Probably related to } \\
\text { loss of Māori land } \\
\text { and his involvement } \\
\text { in the NZ Wars } \\
\text { against Māori [12] } \\
\text { (see Table S3) }\end{array}$ & $\begin{array}{l}\text { Head replaced and } \\
\text { paint removed }\end{array}$ \\
\hline $\begin{array}{l}\text { Ballance, John } \\
\text { (Moutoa } \\
\text { Gardens, } \\
\text { Whanganui) }\end{array}$ & $\begin{array}{l}\text { Prime Minister } \\
\text { of NZ }\end{array}$ & Yes & $\begin{array}{l}\text { Decapitation in both } \\
1994 \text { and } 1995 \text { [12]. } \\
\text { Then after a further } \\
\text { period the torso } \\
\text { disappeared (1995) }\end{array}$ & See above & $\begin{array}{l}\text { Statue never } \\
\text { replaced at this site } \\
\text { but a bronze one } \\
\text { was subsequently } \\
\text { unveiled elsewhere } \\
\text { in the city (see } \\
\text { below) }\end{array}$ \\
\hline $\begin{array}{l}\text { Ballance, John } \\
\text { (Whanganui - } \\
\text { Council } \\
\text { Buildings) }\end{array}$ & $\begin{array}{l}\text { Prime Minister } \\
\text { of NZ }\end{array}$ & Yes & Foot stolen & See above & $\begin{array}{l}\text { Foot replaced. } \\
\text { "When the statue } \\
\text { was sent back to } \\
\text { the sculptor for } \\
\text { repairs, it was } \\
\text { discovered it had } \\
\text { not been cast } \\
\text { properly and } \\
\text { needed to be } \\
\text { completely rebuilt" } \\
\text { [28]. }\end{array}$ \\
\hline $\begin{array}{l}\text { Burns, Robert } \\
\text { (Timaru) }\end{array}$ & Scottish poet & No & Decapitation (2012) & $\begin{array}{l}\text { Unknown - } \\
\text { possibly a prank }\end{array}$ & Head replaced \\
\hline $\begin{array}{l}\text { Burns, Robert } \\
\text { (Hokitika) }\end{array}$ & Scottish poet & No & $\begin{array}{l}\text { Missing nose and } \\
\text { signs of previous } \\
\text { repair (Fig. 2, main } \\
\text { text); Repairs to } \\
\text { hand and foot } \\
\text { evident. }\end{array}$ & $\begin{array}{l}\text { Unknown - } \\
\text { possibly a prank }\end{array}$ & $\begin{array}{l}\text { Nose still missing } \\
\text { with wires visible in } \\
\text { nasal area; poor } \\
\text { quality repair to } \\
\text { hand. }\end{array}$ \\
\hline $\begin{array}{l}\text { Cook, James } \\
\text { [Captain] (Kaiti } \\
\text { Hill, Gisborne) }\end{array}$ & $\begin{array}{l}\text { Explorer (with } \\
\text { his expedition } \\
\text { first landing in } \\
\text { NZ in the } \\
\text { Gisborne area) }\end{array}$ & Yes & $\begin{array}{l}\text { Multiple paint attacks } \\
\text { (eg, red paint on } \\
\text { face, white bikini in } \\
\text { past decade) }\end{array}$ & $\begin{array}{l}\text { Probably } \\
\text { associated with } \\
\text { local Māori killed at } \\
\text { the time of Cook's } \\
\text { visit; possibly also } \\
\text { symbolising the } \\
\text { start of the loss of } \\
\text { Māori land to }\end{array}$ & $\begin{array}{l}\text { Cleaned - but in } \\
2019 \text { the relevant } \\
\text { City Council moved } \\
\text { the statue to a local } \\
\text { museum }\end{array}$ \\
\hline
\end{tabular}




\begin{tabular}{|c|c|c|c|c|c|}
\hline $\begin{array}{l}\text { Name of the } \\
\text { memorialised } \\
\text { person } \\
\text { (locality) }\end{array}$ & $\begin{array}{l}\text { Reason for } \\
\text { fame }\end{array}$ & $\begin{array}{l}\text { Classified } \\
\text { as contro- } \\
\text { versial }\end{array}$ & $\begin{array}{l}\text { Nature of injuries/ } \\
\text { damage (dates) }\end{array}$ & $\begin{array}{l}\text { Possible reason/s } \\
\text { for damage }\end{array}$ & Outcomes \\
\hline & & & & $\begin{array}{l}\text { Europeans (see } \\
\text { Table S3) }\end{array}$ & \\
\hline $\begin{array}{l}\text { Cook, James } \\
\text { [Captain] } \\
\text { (foreshore, } \\
\text { Gisborne) }\end{array}$ & $\begin{array}{l}\text { Explorer (with } \\
\text { his expedition } \\
\text { first landing in } \\
N Z \text { in the } \\
\text { Gisborne area) }\end{array}$ & Yes & $\begin{array}{l}\text { Multiple attacks of } \\
\text { red paint to face and } \\
\text { mid-section (last } \\
\text { decade, eg, 2016) }\end{array}$ & See above & Paint removed \\
\hline $\begin{array}{l}\text { Cook, James } \\
\text { (Christchurch) }\end{array}$ & Explorer & Yes & $\begin{array}{l}\text { Graffiti (field } \\
\text { observation) - } \\
\text { possibly tagging }\end{array}$ & See above & Unknown \\
\hline $\begin{array}{l}\text { Crumen, } \\
\text { Barrett } \\
\text { ("Russian } \\
\text { Jack") } \\
\text { (Masterton) }\end{array}$ & $\begin{array}{l}\text { Local } \\
\text { character/ } \\
\text { itinerant } \\
\text { labourer } \\
\text { (swagger) }\end{array}$ & No & $\begin{array}{l}\text { Likely paint attack } \\
\text { given remains of } \\
\text { paint on the face } \\
\text { (bronze statue) found } \\
\text { in field observations }\end{array}$ & Unknown & $\begin{array}{l}\text { Paint appears to } \\
\text { have been largely } \\
\text { removed }\end{array}$ \\
\hline $\begin{array}{l}\text { George V } \\
\text { [King] } \\
\text { (Matakana) }\end{array}$ & $\begin{array}{l}\text { King of the UK } \\
\text { and the British } \\
\text { Dominions } \\
\text { (including NZ) }\end{array}$ & Yes & $\begin{array}{l}\text { Decapitated a total of } \\
5 \text { times (eg, Fig. } 2 \\
\text { from 2013, main text) }\end{array}$ & $\begin{array}{l}\text { Unknown - } \\
\text { possibly pranks but } \\
\text { conceivably related } \\
\text { to this statue being } \\
\text { on a war memorial } \\
\text { and George } \mathrm{V} \\
\text { being a military } \\
\text { leader (see Table } \\
\text { S3) }\end{array}$ & $\begin{array}{l}\text { Head replaced each } \\
\text { time (combined with } \\
\text { other restoration } \\
\text { work) }\end{array}$ \\
\hline $\begin{array}{l}\text { Grey, George } \\
\text { [Sir] } \\
\text { (Auckland) }\end{array}$ & $\begin{array}{l}\text { Governor of } \\
\text { NZ; Premier of } \\
\text { NZ }\end{array}$ & Yes & $\begin{array}{l}\text { Paint attack (1952), } \\
\text { subsequent theft of } \\
\text { hands in subsequent } \\
\text { decade or so; } \\
\text { Decapitation (1987) }\end{array}$ & $\begin{array}{l}\text { Involvement in the } \\
\text { NZ Wars where } \\
\text { Māori land was } \\
\text { taken [10] (see } \\
\text { Table S3) }\end{array}$ & $\begin{array}{l}\text { Repairs conducted; } \\
\text { Head never } \\
\text { recovered and so a } \\
\text { new one produced }\end{array}$ \\
\hline $\begin{array}{l}\text { Hamilton, John } \\
\text { [Captain] } \\
\text { (Hamilton) }\end{array}$ & $\begin{array}{l}\text { Military leader/ } \\
\text { City of } \\
\text { Hamilton } \\
\text { named after } \\
\text { him }\end{array}$ & Yes & $\begin{array}{l}\text { Paint attack plus } \\
\text { blows from a } \\
\text { hammer which } \\
\text { appear to have } \\
\text { caused indentations } \\
\text { on the nose (2018). } \\
\text { Other signs of graffiti } \\
\text { on face and back }\end{array}$ & $\begin{array}{l}\text { Involved in the } \\
\text { Battle of Gate Pā } \\
\text { (NZ Wars) where } \\
\text { Māori were killed } \\
\text { (as reported by the } \\
\text { perpetrator in the } \\
\text { media) (see also } \\
\text { Table S3) }\end{array}$ & $\begin{array}{l}\text { Paint largely } \\
\text { removed. } \\
\text { Indentations and } \\
\text { graffiti (black marker } \\
\text { pen) visible in } \\
\text { December } 2018 \\
\text { (field visit) }\end{array}$ \\
\hline $\begin{array}{l}\text { Holyoake, } \\
\text { Keith } \\
\text { (Wellington) }\end{array}$ & Prime Minister & Yes & $\begin{array}{l}\text { Paint attack (red } \\
\text { paint on both hands) } \\
\text { in } 1998 \text { [29] }\end{array}$ & $\begin{array}{l}\text { Reported to be "an } \\
\text { apparent protest } \\
\text { against Vietnam } \\
\text { War } \\
\text { commemorations } \\
\text { occurring at the } \\
\text { time" (Holyoake } \\
\text { was involved in } \\
\text { sending NZ troops } \\
\text { to Vietnam, see } \\
\text { Table S3) }\end{array}$ & Paint removed \\
\hline
\end{tabular}




\begin{tabular}{|c|c|c|c|c|c|}
\hline $\begin{array}{l}\text { Name of the } \\
\text { memorialised } \\
\text { person } \\
\text { (locality) }\end{array}$ & $\begin{array}{l}\text { Reason for } \\
\text { fame }\end{array}$ & $\begin{array}{l}\text { Classified } \\
\text { as contro- } \\
\text { versial }\end{array}$ & $\begin{array}{l}\text { Nature of injuries/ } \\
\text { damage (dates) }\end{array}$ & $\begin{array}{l}\text { Possible reason/s } \\
\text { for damage }\end{array}$ & Outcomes \\
\hline $\begin{array}{l}\text { Jellicoe, John } \\
\text { Rushworth } \\
\text { [Earl] } \\
\text { (Invercargill) }\end{array}$ & $\begin{array}{l}\text { Military leader } \\
\text { and Governor } \\
\text { General of NZ }\end{array}$ & Yes & $\begin{array}{l}\text { Missing a nose (see } \\
\text { Fig. S1), probably } \\
\text { due to vandalism } \\
\text { (2008) }\end{array}$ & $\begin{array}{l}\text { Unknown - } \\
\text { possibly a prank; } \\
\text { possibly an anti-war } \\
\text { statement as he } \\
\text { was a military } \\
\text { leader (see Table } \\
\text { S3) }\end{array}$ & $\begin{array}{l}\text { After having no } \\
\text { nose for } 10 \text { years, it } \\
\text { was replaced in } \\
2018 \text { - albeit with } \\
\text { suboptimal } \\
\text { alignment (field } \\
\text { observations) }\end{array}$ \\
\hline $\begin{array}{l}\text { Kipling, } \\
\text { Rudyard } \\
\text { (Christchurch) }\end{array}$ & Writer & No & $\begin{array}{l}\text { Blue paint marks on } \\
\text { field observations }\end{array}$ & $\begin{array}{l}\text { Unknown - } \\
\text { possibly a prank }\end{array}$ & Unknown \\
\hline $\begin{array}{l}\text { Kitchener, } \\
\text { Horatio } \\
\text { Herbert [Field } \\
\text { Marshal] } \\
\text { (Auckland) }\end{array}$ & $\begin{array}{l}\text { Military leader } \\
\text { in World War } \\
\text { One (WW1) }\end{array}$ & Yes & $\begin{array}{l}\text { Decapitation - } \\
\text { probably with an axe } \\
(1931)\end{array}$ & $\begin{array}{l}\text { Unknown - but } \\
\text { possibly related to } \\
\text { First World War } \\
\text { grievances (see } \\
\text { Table S3) }\end{array}$ & $\begin{array}{l}\text { The rest of the } \\
\text { statue was taken } \\
\text { down and never } \\
\text { replaced }\end{array}$ \\
\hline $\begin{array}{l}\text { Kitchener, } \\
\text { Horatio } \\
\text { Herbert [Field } \\
\text { Marshal] } \\
\text { (Invercargill) }\end{array}$ & $\begin{array}{l}\text { Military leader } \\
\text { in World War } \\
\text { One (WW1) }\end{array}$ & Yes & $\begin{array}{l}\text { Nugget (shoe polish) } \\
\text { smeared over face } \\
\text { and other parts } \\
(1932)\end{array}$ & See above & Cleaned \\
\hline $\begin{array}{l}\text { Plimmer, John } \\
\text { (Wellington) }\end{array}$ & $\begin{array}{l}\text { Business } \\
\text { leader }\end{array}$ & No & $\begin{array}{l}\text { Paint attack - looking } \\
\text { like tagging marks } \\
(2011) \text { and possibly } \\
\text { related to an All } \\
\text { Blacks Parade in the } \\
\text { city a few hours later }\end{array}$ & $\begin{array}{l}\text { Unknown - } \\
\text { possibly a prank }\end{array}$ & Paint removed \\
\hline $\begin{array}{l}\text { Ruskin, John } \\
\text { (Christchurch) }\end{array}$ & $\begin{array}{l}\text { Art critic, } \\
\text { writer, artist, } \\
\text { social activist }\end{array}$ & No & $\begin{array}{l}\text { Missing nose at time } \\
\text { of field observations }\end{array}$ & $\begin{array}{l}\text { Unknown - } \\
\text { possibly a prank }\end{array}$ & Unknown \\
\hline $\begin{array}{l}\text { Tait, Gordon } \\
\text { [Admiral Sir] } \\
\text { (Timaru) }\end{array}$ & Military leader & Yes & $\begin{array}{l}\text { Stolen and never } \\
\text { recovered }\end{array}$ & $\begin{array}{l}\text { Unknown - } \\
\text { possibly for the } \\
\text { scrap metal }\end{array}$ & $\begin{array}{l}\text { A new bust was } \\
\text { made and more } \\
\text { securely fastened } \\
\text { than previously } \\
\end{array}$ \\
\hline $\begin{array}{l}\text { Te Awe Awe, } \\
\text { Te Peeti } \\
\text { (Palmerston } \\
\text { North) }\end{array}$ & $\begin{array}{l}\text { Māori Chief } \\
\text { involved in the } \\
\text { NZ Wars and } \\
\text { also land sales } \\
\text { (while also } \\
\text { opposing the } \\
\text { colonial } \\
\text { government) }\end{array}$ & Yes & $\begin{array}{l}\text { Red paint attack } \\
\text { (2018) with message } \\
\text { painted on the } \\
\text { surrounding ground: } \\
\text { "Kawana land stolen" }\end{array}$ & $\begin{array}{l}\text { Probably inter-tribal } \\
\text { issues around } \\
\text { Māori land loss (ie, } \\
\text { "Kawana land } \\
\text { stolen") (see also } \\
\text { Table S3) }\end{array}$ & Paint removed \\
\hline $\begin{array}{l}\text { Upham, } \\
\text { Charles }\end{array}$ & $\begin{array}{l}\text { Military hero } \\
\text { (two Victoria } \\
\text { Crosses) }\end{array}$ & Yes & $\begin{array}{l}\text { Attempt at cutting it } \\
\text { down at the base } \\
\text { with a concrete cutter } \\
\text { (1998) }\end{array}$ & $\begin{array}{l}\text { Anti-military action } \\
\text { by a perpetrator } \\
\text { who had a long } \\
\text { history of anti- } \\
\text { military protests in }\end{array}$ & $\begin{array}{l}\text { Fully repaired. } \\
\text { Perpetrator fined } \\
\$ 600\end{array}$ \\
\hline
\end{tabular}




\begin{tabular}{|c|c|c|c|c|c|}
\hline $\begin{array}{l}\text { Name of the } \\
\text { memorialised } \\
\text { person } \\
\text { (locality) }\end{array}$ & $\begin{array}{l}\text { Reason for } \\
\text { fame }\end{array}$ & $\begin{array}{l}\text { Classified } \\
\text { as contro- } \\
\text { versial }\end{array}$ & $\begin{array}{l}\text { Nature of injuries/ } \\
\text { damage (dates) }\end{array}$ & $\begin{array}{l}\text { Possible reason/s } \\
\text { for damage }\end{array}$ & Outcomes \\
\hline & & & & $\begin{array}{l}\text { NZ (see also Table } \\
\text { S3) }\end{array}$ & \\
\hline $\begin{array}{l}\text { Victoria, } \\
\text { [Queen] } \\
\text { (Auckland) }\end{array}$ & $\begin{array}{l}\text { Queen of the } \\
\text { UK and the } \\
\text { British } \\
\text { Dominions } \\
\text { (including NZ) }\end{array}$ & No & $\begin{array}{l}\text { Paint attack in } 1952 \\
\text { in conjunction with } \\
\text { one on the nearby } \\
\text { statue of Grey }\end{array}$ & $\begin{array}{l}\text { Probably a political } \\
\text { component with the } \\
\text { words "Ravager of } \\
\text { the Māoris" written } \\
\text { on the nearby } \\
\text { statue of Grey in } \\
\text { the simultaneous } \\
\text { attack [12] (see } \\
\text { also Table S3) }\end{array}$ & Repaired \\
\hline $\begin{array}{l}\text { Victoria, } \\
\text { [Queen] } \\
\text { (Dunedin) }\end{array}$ & $\begin{array}{l}\text { Queen of the } \\
\text { UK and the } \\
\text { British } \\
\text { Dominions } \\
\text { (including NZ) }\end{array}$ & No & $\begin{array}{l}\text { Nose smashed and } \\
\text { black paint attack } \\
\text { (mid-1990s); damage } \\
\text { to fingers (unknown } \\
\text { date) }\end{array}$ & $\begin{array}{l}\text { Unknown - some } \\
\text { might be pranks to } \\
\text { place traffic cones } \\
\text { on her head (but } \\
\text { see also the row } \\
\text { above and Table } \\
\text { S3) }\end{array}$ & $\begin{array}{l}\text { Repairs to nose } \\
\text { (Fig. 2, main text) } \\
\text { and fingers although } \\
\text { there is residual } \\
\text { poor alignment of } \\
\text { the nose repair; } \\
\text { Paint removed }\end{array}$ \\
\hline $\begin{array}{l}\text { Wakefield, } \\
\text { Edward } \\
\text { Gibbon } \\
\text { (Wellington) }\end{array}$ & $\begin{array}{l}\text { A founder of } \\
\text { the European } \\
\text { colonisation of } \\
\text { NZ }\end{array}$ & Yes & $\begin{array}{l}\text { Indentations to nose, } \\
\text { cheeks, brow, and an } \\
\text { eyebrow (unknown } \\
\text { date) }\end{array}$ & $\begin{array}{l}\text { Unknown - } \\
\text { possibly relating to } \\
\text { his role of a } \\
\text { promoter of } \\
\text { colonisation (see } \\
\text { Table S3), (with this } \\
\text { more likely than his } \\
\text { imprisonment for } \\
\text { child abduction) }\end{array}$ & Remains unrepaired \\
\hline $\begin{array}{l}\text { Wellington, } \\
\text { [Duke of] } \\
\text { (Wellington) }\end{array}$ & $\begin{array}{l}\text { Military leader } \\
\text { and a NZ city } \\
\text { named after } \\
\text { him }\end{array}$ & Yes & $\begin{array}{l}\text { Indentations to nose, } \\
\text { cheek, brow, } \\
\text { eyebrow and chin } \\
\text { (unknown date). } \\
\text { Signs of gold paint } \\
\text { on the face and in } \\
\text { ear (unknown date) }\end{array}$ & $\begin{array}{l}\text { Unknown - but was } \\
\text { a military leader } \\
\text { (see Table S3) }\end{array}$ & $\begin{array}{l}\text { Remains unrepaired } \\
\text { except for likely } \\
\text { removal of paint }\end{array}$ \\
\hline $\begin{array}{l}\text { Young, } \\
\text { Nicholas }\end{array}$ & $\begin{array}{l}\text { First of } \\
\text { Captain James } \\
\text { Cook's crew to } \\
\text { see New } \\
\text { Zealand }\end{array}$ & No & Paint attack in 2016 & $\begin{array}{l}\text { Probably related to } \\
\text { the attacks on the } \\
\text { two statues of } \\
\text { Captain Cook } \\
\text { around this time } \\
\text { which are also in } \\
\text { Gisborne (see } \\
\text { above and Table } \\
\text { S3) }\end{array}$ & Paint removed \\
\hline
\end{tabular}


Fig. S1: Marble statue of the military leader Earl Jellicoe (Invercargill City) showing a replacement nose that was preceded by 10 years of having no nose (photo: by $1^{\text {st }}$ author 2019)

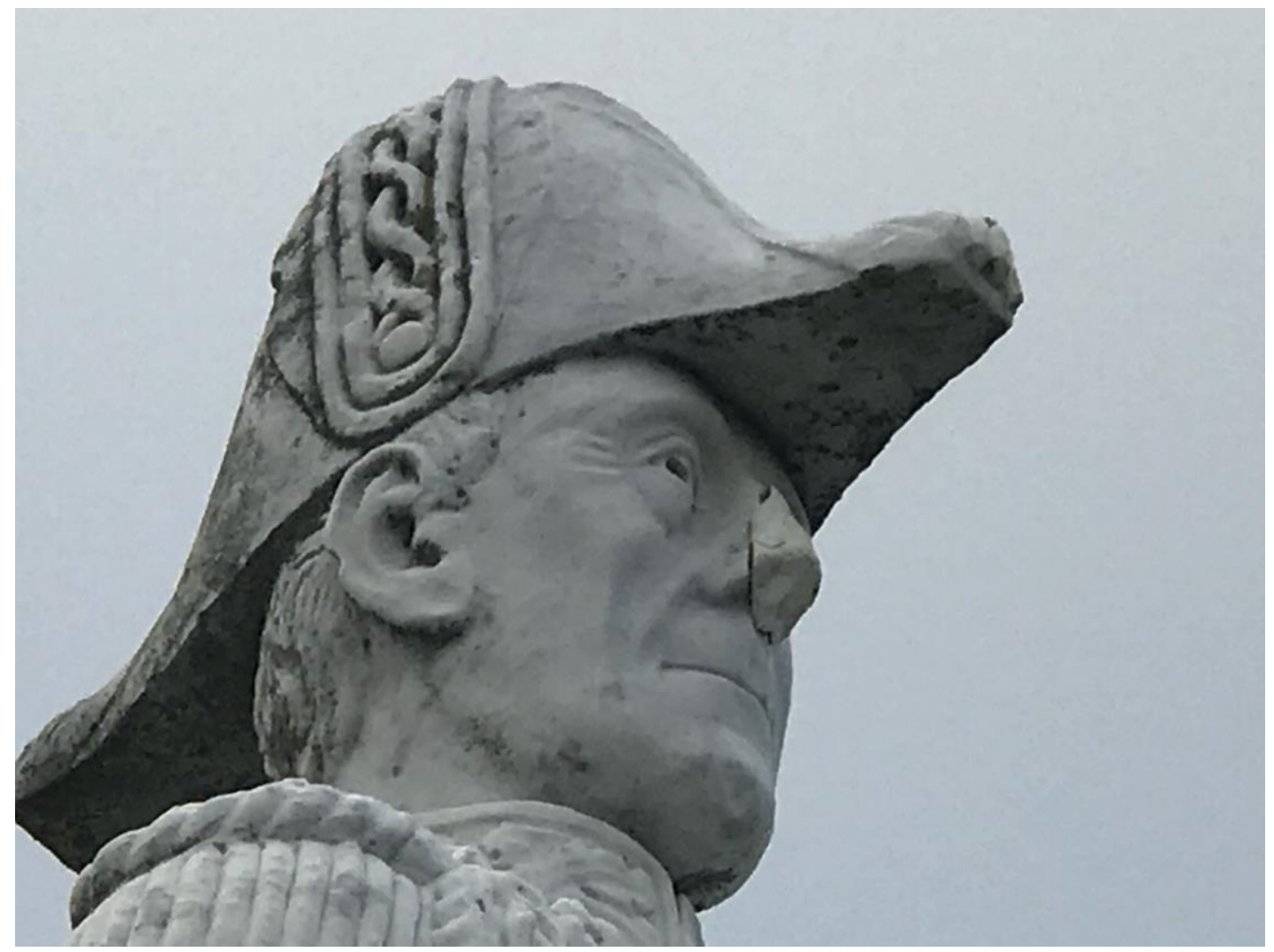


Fig. S2: Marble statue of the Māori soldier Herewini Whakarua (Whanganui) on a high plinth which made close examination of the statue more difficult in this study (photo: $1^{\text {st }}$ author 2018)

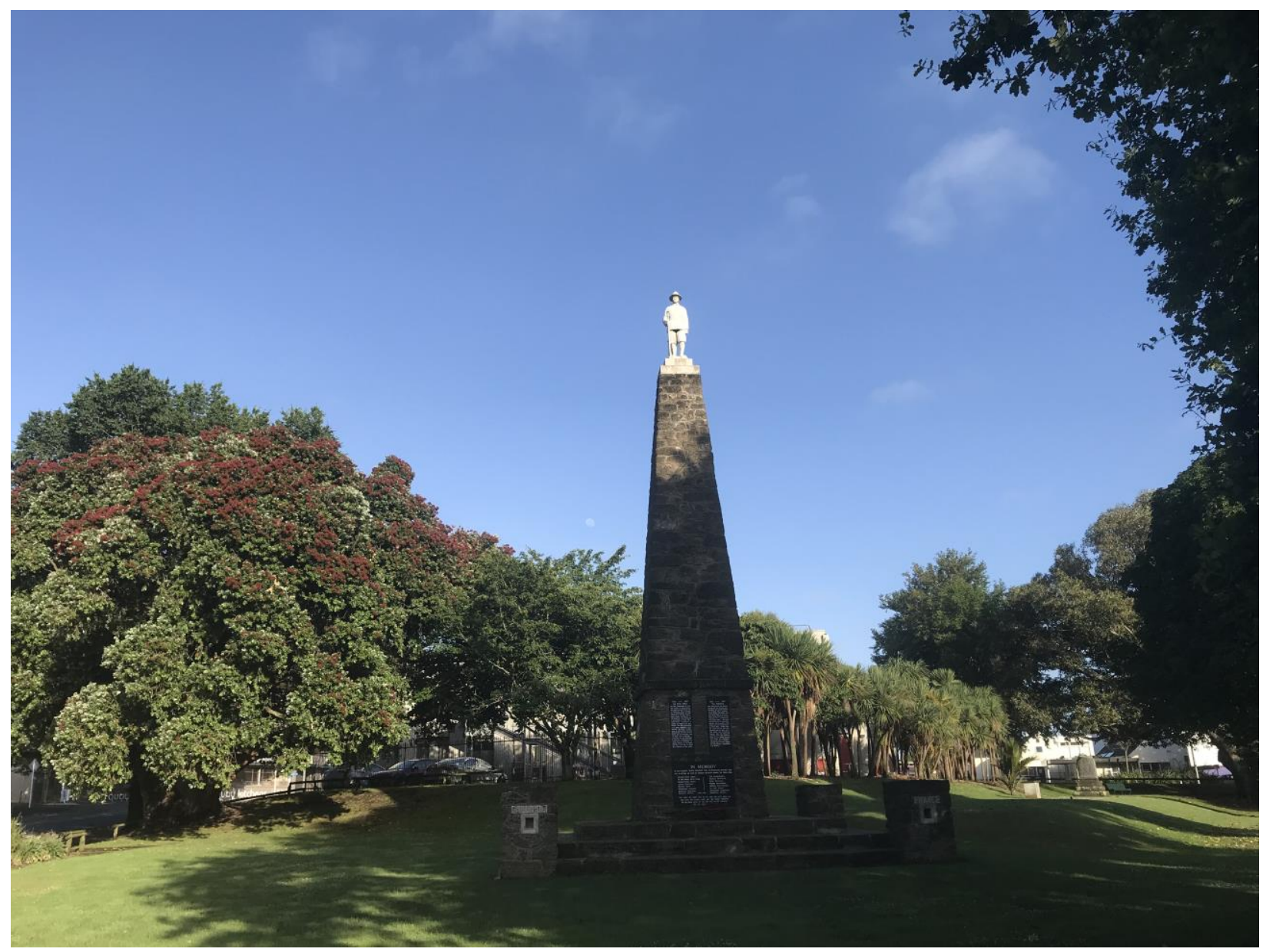


Fig. S3: Statue of the rugby hero Michael Jones (Auckland), the only statue of a person with Pacific peoples ethnicity identified in the survey (photo: $1^{\text {st }}$ author 2019).

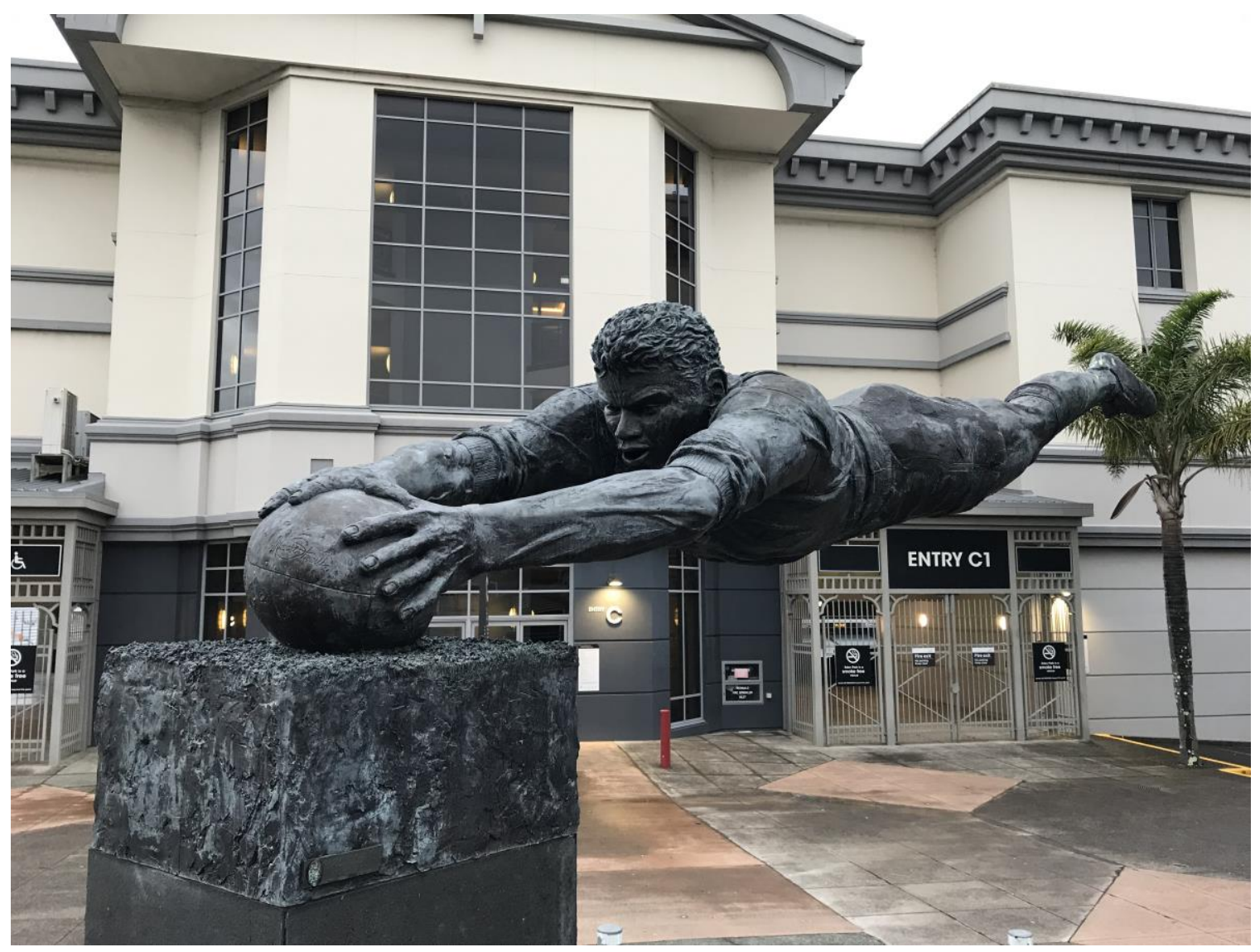


Fig. S4: Statue of a local doctor (Dr Charles Little, Waikari) with evidence of lichen growth (photo: $2^{\text {nd }}$ author 2019)

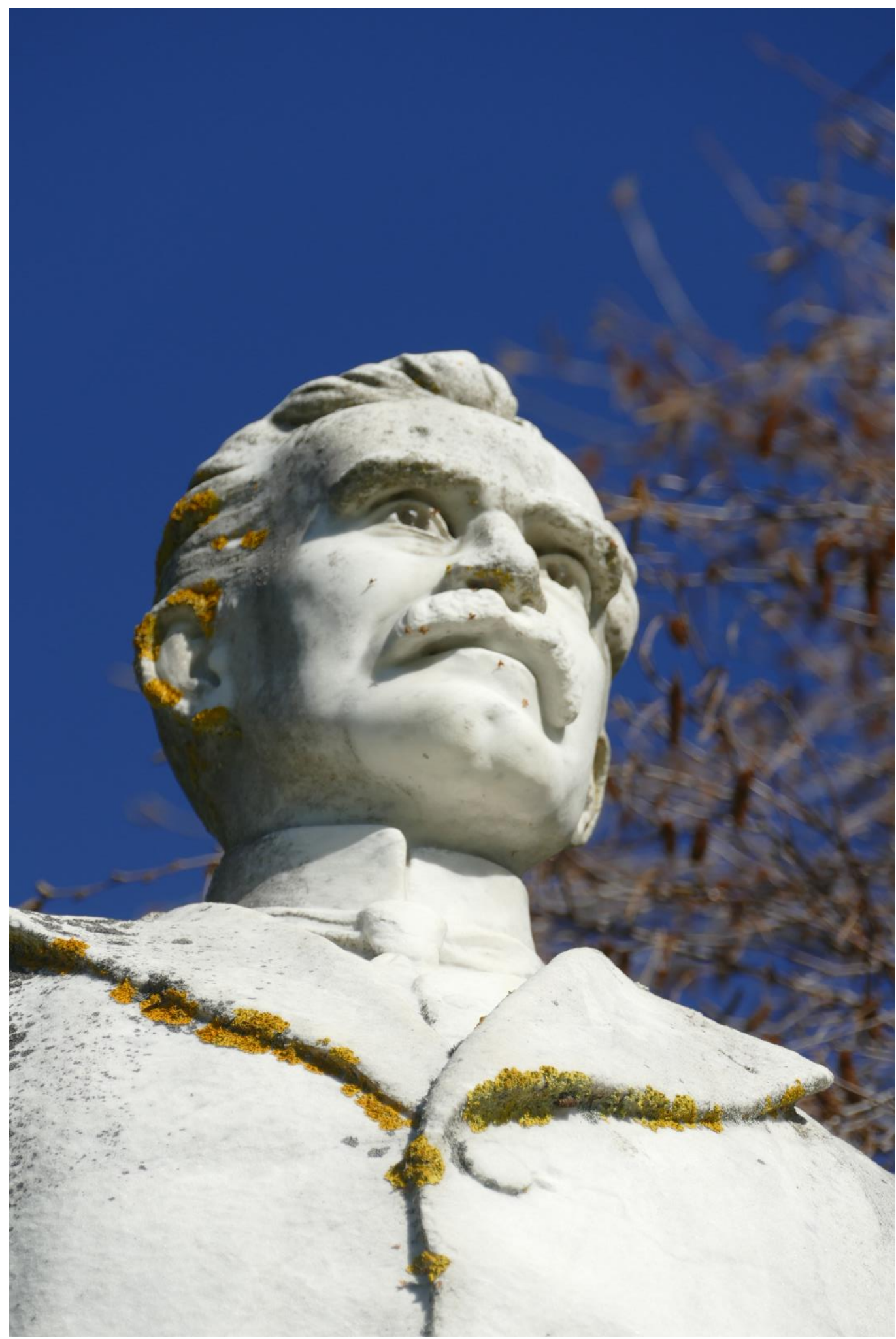




\section{References}

1. Dunn M. New Zealand sculpture: A history. Auckland: Auckland University Press; 2002.

2. Harper J, Lister A, Connew B. Wellington, A City for Sculpture. Wellington: Victoria University Press; 2007.

3. Maclean C, Phillips J. The sorrow and the pride: New Zealand war memorials. Wellington, Historical Branch with GP Books, 1990.

4. Phillips J. 'Memorials and monuments', Te Ara - the Encyclopedia of New Zealand. (Published 20 June 2012, updated 26 March 2015). http://www.TeAra.govt.nz/en/memorials-and-monuments (accessed 20 September 2018).

5. Wellington City Council. Sculptures \& Memorials. https://wellington.govt.nz/services/community-and-culture/arts/outdoor-publicart/sculptures-and-memorials (accessed 20 September).

6. Christchurch City Libraries. Christchurch statues. https://my.christchurchcitylibraries.com/statues/ (accessed 21 September 2018).

7. van der Krogt R, Peter van der Krogt P. Statues - Hither \& Thither: New Zealand (last update 24 September 2018. http://vanderkrogt.net/statues/land.php?land=NZ\&webpage=ST\&page=1.

8. Wikipedia. New Zealand's Top 100 History Makers. https://en.m.wikipedia.org/wiki/New_Zealand\%27s_Top_100_History_Makers (accessed 21 September 2018).

9. National Library of New Zealand. Papers Past: Newspapers. https://paperspast.natlib.govt.nz/newspapers (accessed 30 September 2018).

10. Stocker M. "Director of the Canoe": The Auckland Statue of Sir George Grey. Melbourne Art Journal. 2009;11-12:57-8.

11. Buchanan R. Why Gandhi doesn't belong at Wellington Railway Station. Journal of Social History. 2011;44(4):1077-93.

12. Morris E. Men alone, in bronze and stone: A tale of two statues. Journal of New Zealand Studies. 2012;NS13:62-76.

13. Stocker M. 'A token of their love': Queen Victoria Memorials in New Zealand. 19: Interdisciplinary Studies in the Long Nineteenth Century, 2016(22). DOI: http://doi.org/10.16995/ntn.724.

14. Wilson N, Ferguson C, Rice G, Baker MG, Schrader B, Clement C, et al. Remembering the 1918 influenza pandemic: national survey of memorials and scope for enhancing educational value around pandemic preparedness. N Z Med J. 2017;130(1465):53-70. Epub 2017/11/10. PubMed PMID: 29121624.

15. McIvor T. 'Ballance, John', Dictionary of New Zealand Biography, first published in 1993. Te Ara - the Encyclopedia of New Zealand, https://teara.govt.nz/en/biographies/2b5/ballance-john (accessed 22 October 2019).

16. Auckland War Memorial Museum. Cenotaph database. http://muse.aucklandmuseum.com/databases/Cenotaph/locations.aspx.

17. Beaglehole T. 'Fraser, Peter', Dictionary of New Zealand Biography, first published in 1998. Te Ara - the Encyclopedia of New Zealand, https://teara.govt.nz/en/biographies/4f22/fraser-peter (accessed 29 October 2019). 
18. McAloon J. Fraser and the First World War (20 December 2016).

https://ww100.govt.nz/fraser-and-the-first-world-war.

19. Orange C. 'Treaty of Waitangi - Māori responses to the treaty - 1880 to 1900 ', Te Ara the Encyclopedia of New Zealand, http://www.TeAra.govt.nz/en/treaty-of-waitangi/page$\underline{5}$ (accessed 22 October 2019).

20. McGibbon I. 'Asian conflicts - Vietnam War', Te Ara - the Encyclopedia of New Zealand, http://www.TeAra.govt.nz/en/asian-conflicts/page-5 (accessed 22 October 2019).

21. Hamer D. 'Seddon, Richard John', Dictionary of New Zealand Biography, first published in 1993. Te Ara - the Encyclopedia of New Zealand, https://teara.govt.nz/en/biographies/2s11/seddon-richard-john (accessed 2 November 2019).

22. Durie M. 'Te Aweawe, Te Peeti', Dictionary of New Zealand Biography, first published in 1990. Te Ara - the Encyclopedia of New Zealand, https://teara.govt.nz/en/biographies/1t27/te-aweawe-te-peeti (accessed 22 October 2019).

23. Dreaver A. 'Te Rangihiwinui, Te Keepa', Dictionary of New Zealand Biography, first published in 1990. Te Ara - the Encyclopedia of New Zealand, https://teara.govt.nz/en/biographies/1t64/te-rangihiwinui-te-keepa (accessed 22 October 2019).

24. Oliver S. 'Te Rauparaha', Dictionary of New Zealand Biography, first published in 1990. Te Ara - the Encyclopedia of New Zealand, https://teara.govt.nz/en/biographies/1t74/terauparaha (accessed 22 October 2019).

25. Orange C. 'Treaty of Waitangi - Dishonouring the treaty - 1860 to 1880 ', Te Ara - the Encyclopedia of New Zealand, http://www.TeAra.govt.nz/en/treaty-of-waitangi/page-4 (accessed 22 October 2019).

26. Fairburn M. 'Wakefield, Edward Gibbon', Dictionary of New Zealand Biography, first published in 1990. Te Ara - the Encyclopedia of New Zealand, https://teara.govt.nz/en/biographies/1w4/wakefield-edward-gibbon (accessed 22 October 2019).

27. McLean G. 'Premiers and prime ministers - Party leadership', Te Ara - the Encyclopedia of New Zealand, http://www.TeAra.govt.nz/en/premiers-and-prime-ministers/page-3 (accessed 29 October 2019).

28. Emerson A-M. Ballance takes up old spot again Wanganui Chronicle 2011;(1 December) https://wwwnzheraldconz/wanganuichronicle/news/articlecfm?c id=1503426\&objectid=11047799.

29. Head J. Statue of former Prime Minister Keith Holyoake with hands painted red, Molesworth Street, Thorndon, Wellington - Photograph taken by Jo Head, [ca 6 May 1998]. Collections of the Alexander Turnbull Library. Reference Number:

EP/1998/1321/19-F. http://mp.natlib.govt.nz/detail/?id=41308\&l=en. 